\title{
Revenue Implications of Destination-Based Cash-Flow Taxation
}

\author{
Hebous, Shafik; Klemm, Alexander; Stausholm, Saila
}

Document Version

Final published version

DOI:

$10.5089 / 9781484392935.001$

Publication date:

2019

License

CC BY-NC-ND

Citation for published version (APA):

Hebous, S., Klemm, A., \& Stausholm, S. (2019). Revenue Implications of Destination-Based Cash-Flow Taxation. International Monetary Fund. IMF Working Paper No. 2019/7CESifo Working Paper No. 7457 https://doi.org/10.5089/9781484392935.001

Link to publication in CBS Research Portal

\section{General rights}

Copyright and moral rights for the publications made accessible in the public portal are retained by the authors and/or other copyright owners and it is a condition of accessing publications that users recognise and abide by the legal requirements associated with these rights.

\section{Take down policy}

If you believe that this document breaches copyright please contact us (research.lib@cbs.dk) providing details, and we will remove access to the work immediately and investigate your claim. 


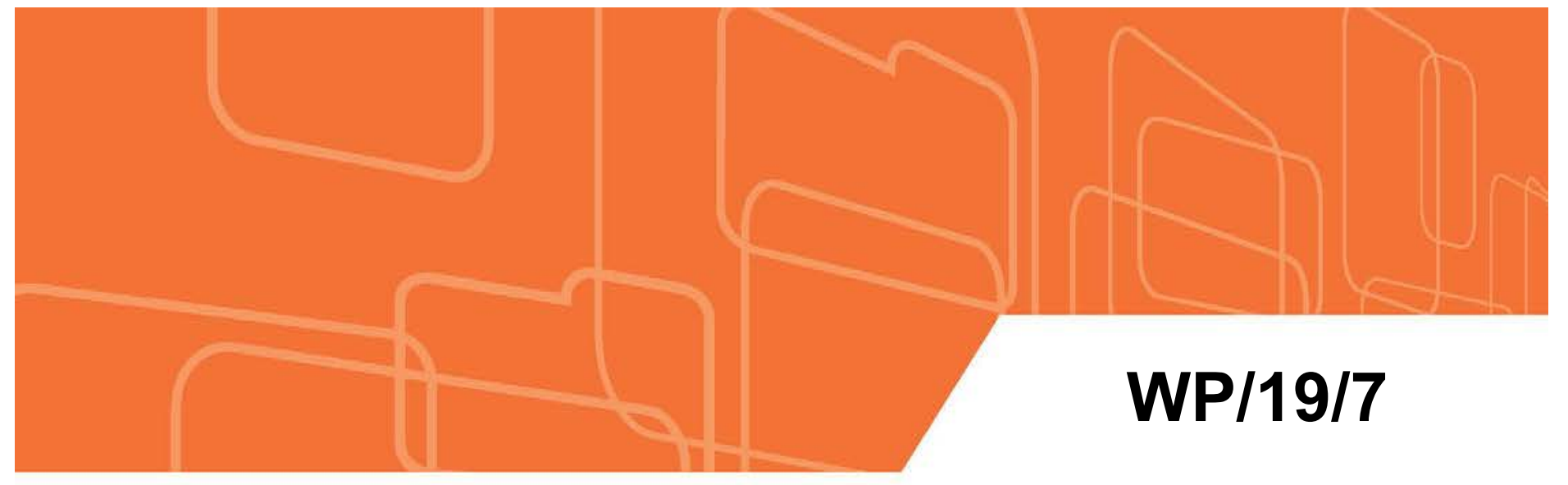

\section{IMF Working Paper}

Revenue Implications of Destination-Based Cash-Flow Taxation

by Shafik Hebous, Alexander Klemm, and Saila Stausholm 


\title{
IMF Working Paper
}

Fiscal Affairs Department

\author{
Revenue Implications of Destination-Based Cash-Flow Taxation \\ Prepared by Shafik Hebous, Alexander Klemm, and Saila Stausholm ${ }^{1}$ \\ Authorized for distribution by Ruud De Mooij
}

January 2019

IMF Working Papers describe research in progress by the author(s) and are published to elicit comments and to encourage debate. The views expressed in IMF Working Papers are those of the author(s) and do not necessarily represent the views of the IMF, its Executive Board, or IMF management.

\begin{abstract}
We estimate the revenue implications of a Destination Based Cash Flow Tax (DBCFT) for 80 countries. On a global average, DBCFT revenues under unchanged tax rates would remain similar to the existing corporate income tax (CIT) revenue, but with sizable redistribution of revenue across countries. Countries are more likely to gain revenue if they have trade deficits, are not reliant on the resource sector, and/or-perhaps surprisingly-are developing economies. DBCFT revenues tend to be more volatile than $\mathrm{CIT}$ revenues. Moreover, we consider the revenue losses resulting from spillovers in case of unilateral implementation of a DBCFT. Results suggest that these spillover effects are sizeable if the adopting country is large and globally integrated. These spillovers generate strong revenue-based incentives for many-but not all—other countries to follow the DBCFT adoption.
\end{abstract}

JEL Classification Numbers: H25, H87.

Keywords: Tax Revenue, Destination-Based Cash Flow Tax, Border Adjustment Tax.

Authors' E-Mail Addresses: shebous@imf.org, aklemm@imf.org, sast.ioa@cbs.dk.

\footnotetext{
${ }^{1}$ S. Stausholm is with Copenhagen Business School. We are grateful for comments by Alan Auerbach, Benjamin Carton, Ruud de Mooij, Michael Keen, Aiko Mineshima, Jiri Podpiera, Rafael Portillo, and IMF Seminar participants.
} 


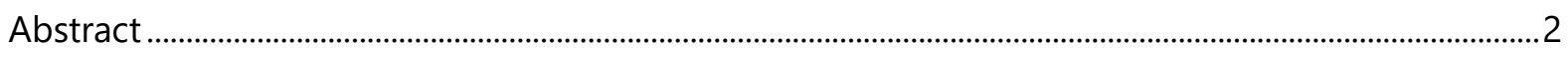

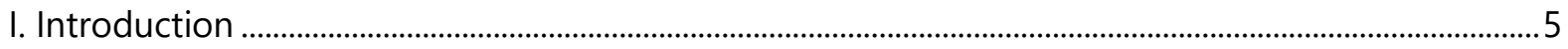

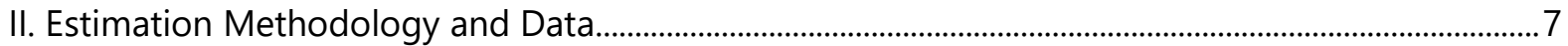

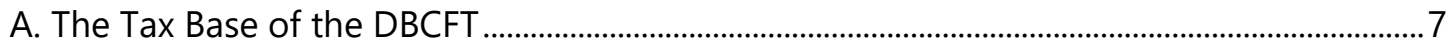

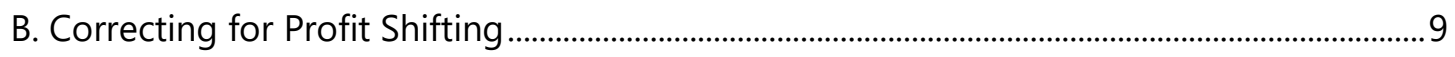

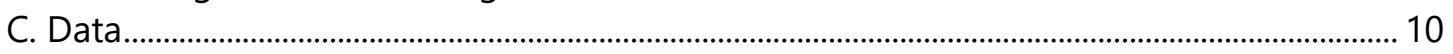

III. Results Under Global Adoption .......................................................................................................... 11

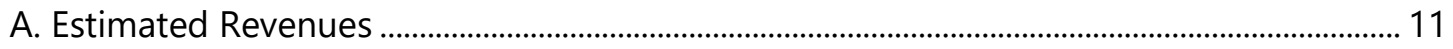

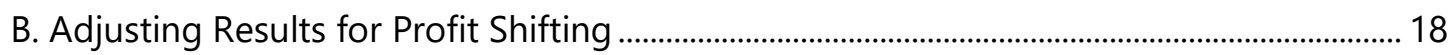

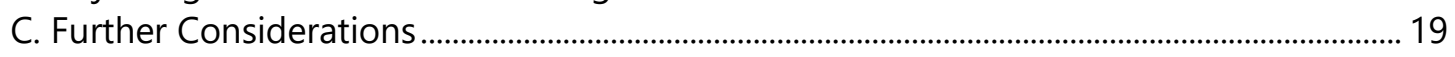

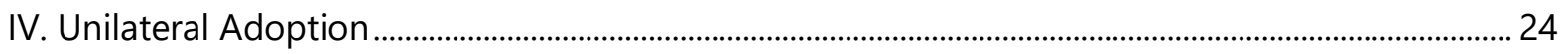

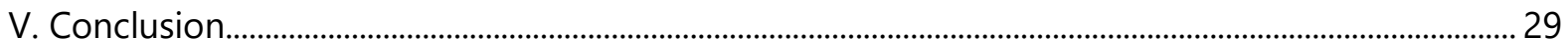

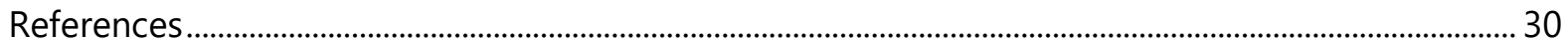

\section{Tables}

1. Descriptive Statistics for Balanced 10-year Panel ................................................................................. 11

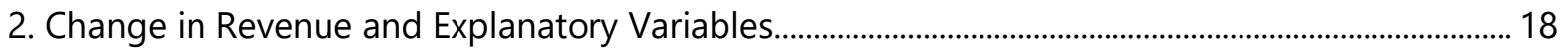

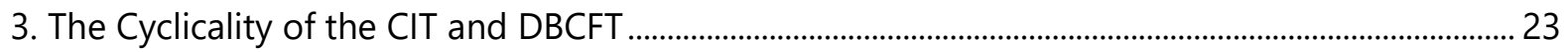

\section{Figures}

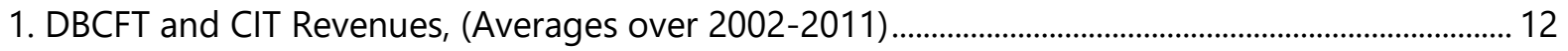

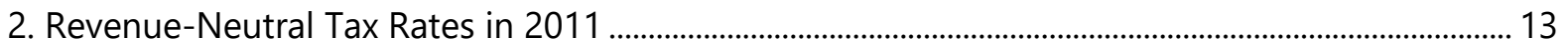

3. Trade balance and Revenue Change, Excluding Resource-Rich Economies .................................... 14

4. Border Adjustment versus Cash Flow Component of Revenue Change ............................................ 14

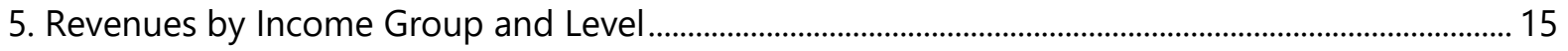

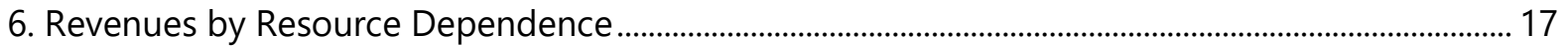

7. The Impact of Adjusting for Profit Shifting ............................................................................................. 19

8. Trade Balance and Net International Investment Position, 2014 ......................................................... 21

9. Standard Deviation of Annual Revenue, 2000-2014 …………………….................................................. 22

10. Average Ratios of Losses to Sales, 2005-14 (percent) ............................................................................ 24

11. Revenue Spillovers from Unilateral DBCFT Adoption, 2011 ................................................................ 27

12. Revenue Changes under DBCFT and CIT Following Hypothetical U.S.

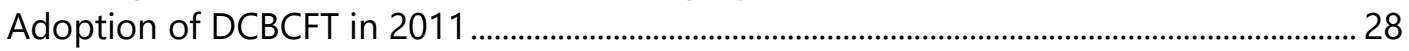

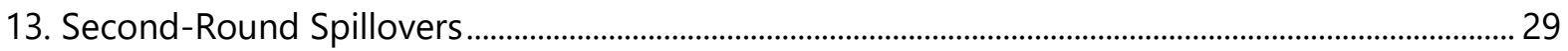

\section{Appendix}




\section{Appendix Tables}

A1. Tax Payments and Incidence for Firms Located in DB...

A2. Tax Payments and Incidence Depending on Ownership. 


\section{INTRODUCTION}

There is an intense debate about the vulnerability of current corporate income tax (CIT) arrangements to profit shifting practices by Multinational Enterprises (MNEs) and tax competition between countries. One approach to addressing these challenges is through reforms within the current system, such as by tightening anti-tax avoidance rules and enhancing tax transparency-e.g., through the G20-OECD Base Erosion and Profit Shifting (BEPS) initiative. Another approach is a fundamental reform of profit taxation that would resolve the vulnerabilities to profit shifting and tax competition.

One specific option for a fundamental reform is a destination-based cash-flow tax (DBCFT), occasionally referred to-slightly misleadingly-as a border-adjusted corporate income tax or a border-adjustment tax. The DBCFT was first proposed in Bond and Devereux (2002) and recently further analyzed in various papers (e.g., Auerbach and others (2017a; 2017b)). Beyond the academic interest, in 2017 the U.S. congressmen Ryan and Brady proposed introducing a variant of the DBCFT in the United States. ${ }^{2}$ While the U.S. tax reform in December 2017 ultimately did not include a DBCFT, the proposal triggered unprecedented policy interest in destination-based profit taxation.

The DBCFT has two components. First, a cash-flow component that enables full expensing of investment and denies interest expense deduction. This component ensures that the DBCFT is a tax on economic rents, leaving normal returns untaxed. Second, the border-adjustment component (i.e., destination-based principle) denies the deduction of imported inputs and excludes revenues from exports from the tax base. This shifts the tax from an origin to a destination base. The DBCFT is thus a rent tax collected at destination. ${ }^{3}$

The DBCFT triggered a discussion on a variety of matters. One much discussed issue is the impact on trade, given the taxation of imports and exemption of exports. Based on theoretical considerations, there should be no impact as changes in real effective exchange rates are expected to undo the impact of the tax. ${ }^{4}$ Whether this applies fully in practice is subject to some debate. ${ }^{5}$ Certainly under fixed exchange rates, adjustment will have to occur through the price level, which would take some time. Apart from the economic impact, there is also a legal debate

\footnotetext{
${ }^{2}$ See: A Better Way Forward-Our Vision for a Confident America, Tax, June 24, 2016.

3 There are other forms of a destination-based business profit tax. For example, Hebous and Klemm (2018) discuss a destination-based allowance for corporate equity (DBACE), including its revenue implications and how they deviate from those of a DBCFT in the short (greater revenue for the DBACE) and long run (no difference in present discounted value terms, but less volatility in case of a DBACE).

${ }^{4}$ This point is made in many papers, for a particularly clear exposition see Auerbach (2017a).

${ }^{5}$ Barbiero and others (2018), for example, argue that the dynamics of adjustment are complex and, depending on anticipation and the exact implementation of the reform, can be incomplete.
} 
on implications under existing tax treaties and world trade rules (e.g., Avi-Yonah and Clausing, 2017).

The purpose of this paper is to contribute to the debate on the pros and cons of a DBCFT by shedding light on one very important empirical question: what are the revenue consequences of adopting a DBCFT? This analysis considers the impact of such an adoption on the tax base, to see how this affects revenues. As a DBCFT is robust to profit shifting and tax competition, revenue losses can in many cases be offset or turned into revenue gains, by raising rates beyond what is currently feasible.

Theoretically, the implications for the tax base are ambiguous: One may be tempted to argue that since the CIT, in theory, taxes both normal return and rent while the DBCFT only taxes rent, the CIT base should be larger. However, many countries provide (often inefficient and ineffective) tax incentives, thereby giving up taxing (a portion of) normal or even supernormal returns. Moreover, MNEs avoidance and tax planning strategies are known to significantly erode the CIT base, especially in high tax countries. Additionally, interest expense deduction from the taxable corporate income can be sizable in some countries. All these factors imply that the actual reported CIT base is not necessarily larger than a destination-based rent tax.

The question should therefore be addressed empirically. Surprisingly, there are, thus far, no cross-country estimates, only estimates for the United States (Patel and McClelland, 2017). The present paper calculates potential DBCFT revenues using an estimated tax base constructed with national accounts data for 80 countries.

Initially, the paper calculates the revenue impact if the tax is applied globally. Our findings suggest that the level of DBCFT revenue, on a global average, is close to the current CIT revenue, given prevailing tax rates. However, a DBCFT significantly redistributes revenues across countries. In particular, countries with trade deficits, developing economies, and/or countries with less reliance on natural resources are more likely to gain (or lose little) revenue under a DBCFT. Regarding the revenue gains of countries with trade deficits, the long-term impact of the DBCFT can be different, as current accounts should balance over time. ${ }^{6}$ To the extent that imports will be financed by future exports, current "winners" from the DBCFT that maintain a negative net international investment position (NIIP) could lose in the long-term, and vice versa.

We also discuss further properties of DBCFT revenues regarding volatility, cyclicality, and the role of loss-making firms. Overall, given the deductibility of investment, the volatility of DBCFT revenue is higher than the $\mathrm{CIT}$, but with substantial variation between countries. Regarding cyclicality, the DBCFT could be expected to be more pro-cyclical, given the investment deductibility or counter-cyclical, given the immediate refunds of taxes on losses. ${ }^{7}$ Empirically, it turns out to be more likely to be procyclical, unlike the CIT which can play a role as an automatic

\footnotetext{
${ }^{6}$ Except if the currency is used as foreign reserve currency.

${ }^{7}$ We assume introduction of a pure DBCFT. The U.S. proposal did not include this feature.
} 
stabilizer. Another effect of immediate tax refunds on losses is an increase in revenue risks from fraudulent and unsuccessful businesses.

As in any empirical analysis, measurement errors can affect the results. As we explain later, based on Auerbach (2017b), potential contamination of existing national account data by profit shifting practices theoretically should not affect our findings. The reason is that mismeasurement of international trade and GDP would offset each other in our approach. Nevertheless, we check this possibility using data corrected for profit shifting obtained from Tørsløv, Wier, and Zucman (2018), which are available for a smaller set of countries. The results are very similar.

Following the analysis of a global introduction, we also consider strategic interactions between countries resulting from unilateral adoption. Global adoption of a DBCFT would mean closing all (known) profit-shifting opportunities, as discussed for example in Auerbach and others (2017b). DBCFT adoption by one country (or a small group) should, however, intensify profit shifting out of countries maintaining a CIT and also encourage moving rent-earning investment out of those countries. This is because the DBCFT reduces to zero, the tax rate on any profits shifted into a DBCFT-adopting country, and also does not tax export-related rents of investors locating real capital in such a country. To shed light on this important issue, we estimate revenue spillover effects from a DBCFT country to the rest of the world. We find that spillover effects are sizeable if the implementing country is large and globally integrated and are pronounced for its major foreign partner countries. The spillovers can be large enough to prompt several countries to follow the DBCFT country in adopting a destination-based tax, leading to second round effects on remaining origin-based countries.

The rest of this paper is structured as follows. Section II discusses how the DBCFT base and revenue can be estimated from available data. Section III presents our results and discusses the factors that determine which countries are likely to gain or lose revenues and possible revenue risk factors. Section IV relaxes the assumption of global adoption and discusses the implication of unilateral adoption by one country. Section $\mathrm{V}$ concludes.

\section{Estimation Methodology and Data}

\section{A. The Tax Base of the DBCFT}

A tax base can be estimated using a top-down approach or a bottom-up approach. The latter is particularly useful for simulating the CIT base and requires detailed administrative tax return data. Commercial (accounting) data can be misleading because in many countries financial accounting conventions differ in important aspects from tax accounting rules, e.g., on depreciation, or the treatment of past losses. Using national accounts for simulating the CIT base is even more challenging, because these statistics average out profits and losses and do not take into account losses carried forward. Moreover, the concept of operating surplus is different from profits under both an accounting and tax definition, notably because it gross of interest. Still, 
economists have tried to estimate tax bases from national accounts, not least because other data—especially administrative data—are not publicly available in many countries. ${ }^{8}$

Fortunately, however, for simulating the DBCFT base, available national accounts data are much more suitable, because they are very close to the definition of the DBCFT base: (i) a DBCFT does not allow interest to be deducted, so using gross operating figures which are gross of interest is an advantage; (ii) a DBCFT should be symmetric to be functional, i.e., tax refunds should be paid to loss-making firms, implying that the use of aggregate profit data that nets out profits and losses of different firms is appropriate; ${ }^{9}$ and (iii) as depreciation is not deductible under the DBCFT, there is no concern about any potential differences between tax and accounting depreciation rates. Thus, national accounts data-which are available for many countriesprovide a useful information for estimating the DBCFT base.

There is more than one possible way of estimating a DBCFT using aggregate statistics. The most straightforward-and as it turns out the one providing the greatest number of observations-is as follows: We start with the nonfinancial ${ }^{10}$ corporate gross operating surplus $(\Pi)$. As this is gross of depreciation (or capital consumption in national account terminology), there is no need for any adjustment, but to obtain the tax base of a cash-flow tax, corporate investment $(I)$ needs to be deducted. To implement the border adjustment, imports $(M)$ are added and exports $(X)$ deducted. Revenues $(R)$ can then be estimated by multiplying the base by the tax rate $(\tau)$ :

$$
R^{D B C F T}=\tau(\Pi-I+M-X)
$$

Note that the tax rate is the statutory rate-including and local rates, where applicable-rather than an effective tax rate, because under a DBCFT depreciation allowances, interest deductibility, and other tax rules would be abolished. Of course, if a country were to keep some special regime, be it a deduction from the tax base or a reduced rate, this would have to be reflected.

Depending on data availability, equivalent calculations could be undertaken. The tax base could be defined starting with value added (VA), deducting compensation of employees (CE), and then adding the border adjustment (equation (2)). Another option would be to start with domestic sales (S) and deducting compensation of employees (equation (3)). In practice, these approaches, especially the one starting with domestic sales yield fewer observations than those under equation (1).

$$
R^{D B C F T}=\tau(V A-C E+M-X)
$$

\footnotetext{
${ }^{8}$ See Ueda (2018) for a discussion of the relationship between national accounts concepts and CIT bases.

${ }^{9}$ Carry-forward, even with interest, would not be effective, because some firms, notably exporters, are likely to be in a systematic tax loss position and would not benefit from it.

${ }^{10}$ To the extent that the financial sector has fee (i.e., non-interest) income that would remain taxable under a DBCFT, this should in principle also be included. The exclusion of such fees leads to a slight downward bias of our revenue estimates.
} 


$$
R^{D B C F T}=\tau(S-C E)
$$

Irrespective of how revenues are estimated, we define the change in revenue as the difference between actual CIT revenues and estimated DBCFT revenues:

$$
\Delta R=R^{D B C F T}-R^{C I T}
$$

The use of actual CIT revenues in this comparison has the advantage that it reflects all complicated aspects of the CIT system that could not be modelled. Under the DBCFT, assuming a clean introduction, there would be no such complications. One disadvantage of comparing actual to theoretical revenues, however, is that actual CIT revenues also reflect compliance. The DBCFT revenue measure, however, implicitly assumes full compliance (at least to the extent that national accounts items are not mis-measured because of noncompliance with the current system). Compliance is likely to be higher under a DBCFT than the current CIT, because there are fewer margins available to companies to reduce tax liabilities. Sales are very hard to falsify, and the border adjustment removes international profit-shifting opportunities. Nevertheless, compliance is unlikely to be full, as some options, such as cross-border shopping, would continue to exist and immediate tax refunds may open the door for tax fraud schemes. The estimate of revenue changes may therefore be slightly biased upward.

\section{B. Correcting for Profit Shifting}

The estimates calculated from the approach above do not take into account that moving to a different tax base would also change behavior. While real investment decisions should change from moving to a neutral tax system, the size of that change is difficult to gauge. ${ }^{11}$ Even the sign is ambiguous, as current tax systems discourage equity-financed investment, but often subsidize debt-financed investment, so moving to a neutral system could boost or reduce the capital stock, depending on the marginal source of funding in a given country. A far greater and more immediate response can be expected on profit shifting.

Under global adoption, a DBCFT would remove any incentive for profit shifting. However, as the current tax system encourages profit shifting, the removal of such incentives would change behavior. Another way to think about it is to consider current macroeconomic statistics, on which our estimates rely, as contaminated by profit shifting. For example, low tax jurisdictions can be expected to have overstated trade balances, because the prices of exported goods likely tend to be exaggerated, and the prices of imported goods understated.

Auerbach (2017b) argues that this is not a concern, because any mismeasurement of the trade balance resulting from profit shifting would also affect measured GDP (or the underlying

\footnotetext{
${ }^{11}$ See Carton, Fernandez-Corugedo, and Hunt (forthcoming) for an analysis of the impact on investment using a multi-region forward-looking DSGE model.
} 
operating surplus in equation (1)). Both effects wash out in estimating the tax base of a DBCFT so that unadjusted figures can be used-which is what we do in most of our reported estimates.

While the argument in Auerbach (2017b) is theoretically compelling, it is not clear whether in practice profit shifting really does affect both statistics in the same way, given that data on the gross operating surplus may be collected differently from trade data, and in particular may include more elements of surveys and estimation. In that case, a sudden disappearance of profit shifting could affect measured trade balances differently from the gross operating surplus.

Tørsløv, Wier, and Zucman (2018) address the issue of profit shifting affecting macroeconomic statistics. They produce and publish statistics that are corrected for profit shifting for 2015, at least for a subsample of the countries we consider. Their data certainly do show a different adjustment for the trade balance and the gross operating surplus when correcting for profit shifting. ${ }^{12}$ Using their data, we can therefore adjust our revenue estimate of equation (1) as follows:

$$
R_{\text {adjusted }}^{D B C F T}=R^{D B C F T}+\tau\left(\Pi_{\text {ajusted }}^{T W Z}-\Pi^{T W Z}-(M-X)_{\text {adjusted }}^{T W Z}+(M-X)^{T W Z}\right)
$$

where TWZ indicates that data are taken from Tørsløv, Wier, and Zucman (2018), while the subscript adjusted indicates that data are corrected for profit shifting. ${ }^{13}$ We use these adjusted series in a robustness check.

\section{Data}

Data for gross operating surplus and investment are taken from the OECD ${ }^{14}$ wherever possible. To extend the sample, data for additional countries are taken from the United Nations Statistics Division. ${ }^{15}$ The UN publishes data from countries calculated using different vintages of the methodology. We use the newest vintage as the starting point, extending the data backward with older vintages by splicing it using the ratio of the most recent common year.

\footnotetext{
${ }^{12}$ An online appendix available at http://gabriel-zucman.eu/missingprofits/ provides data on actual (Table A2) and corrected (Table C5) corporate value added and compensation of employees (the difference of which is the gross operating surplus). The correction to the trade balance is also given (Table $\mathrm{C} 5 \mathrm{~b}$ ). When calculating ratios, it is important to use the adjusted GDP (Table C5) whenever the numerator is adjusted, otherwise unadjusted GDP (Table A1).

${ }^{13}$ Additionally, we calculate an alternative version, where we multiply the adjustment in the gross operating surplus by the ratio of the operating surplus in the nonfinancial sector to the total operating surplus. This is because our approach in equation (1) is based only nonfinancial sector only. So, if part of the adjustment occurs in the financial sector that part, or an estimate thereof, should be excluded from the adjustment. In practice, it does not make a big difference.

${ }^{14}$ Specifically, these are the series: gross operating surplus (nonfinancial accounts, generation of income account, gross operating surplus and mixed income) and investment (gross fixed capital formation - corporations).

15 United Nations Statistics Division: National Accounts Official Country Data: Non-financial corporations.
} 
Data for current revenues are taken from the World Revenue Longitudinal Database (WoRLD). Corporate income tax rate data are taken from the IMF FAD Tax Policy Rates Database and include any local or surtaxes. Data for exports and imports as well as some control variables are taken from the latest published version of the WEO (Spring 2018).

The resulting sample contains data on operating surplus and investment for 80 countries and data for CIT revenues for 73 countries. However, the number of years available vary substantially and do not always overlap. The year with the most observations is 2011 where we can compare 63 countries directly. A relatively large and wide balanced panel covers the years 2002 to 2011, for which there are data for 48 countries. This 10-year panel forms the basis of most of the comparisons over time and is described in Table 1 through selected statistics. Because of data availability, some calculations are made on different sample, which is then indicated in the relevant figure/table headings. For example, for the estimation reflecting the impact of profit shifting, we focus on the year 2015, for which data are available from Tørsløv, Wier, and Zucman (2018). This reduces the sample size is to 37 countries.

\begin{tabular}{|lcccccc|}
\hline \multicolumn{7}{c|}{$\begin{array}{l}\text { Table 1. Descriptive Statistics for Balanced 10-year Panel } \\
\text { (in percent of GDP, unless otherwise noted) }\end{array}$} \\
\hline Variables & Observations & Mean & S.D. & p5 & Median & p95 \\
\hline Imports $(M)$ & 480 & 45.7 & 24.1 & 17.4 & 39.9 & 81.5 \\
Exports $(X)$ & 480 & 45.6 & 27.2 & 16.8 & 40.3 & 83.5 \\
Investment $(I)$ & 480 & 13.8 & 4.5 & 6.6 & 13.4 & 22.0 \\
Gross operating surplus $(I)$ & 480 & 26.2 & 6.1 & 17.5 & 25.3 & 37.8 \\
CIT revenue $\left(R^{C I I}\right)$ & 480 & 3.3 & 1.7 & 1.4 & 2.9 & 6.3 \\
Tax rate $(\tau)$ (in percent) & 480 & 26.8 & 7.3 & 15.0 & 28.0 & 38.9 \\
\hline Source: Authors' calculations. & & & & & \\
\hline
\end{tabular}

\section{Results Under Global Adoption}

\section{A. Estimated Revenues}

We find-maybe surprisingly - that on average across countries and years, revenues from the DBCFT would be close to those obtained from the current CIT. However, there are substantial differences between countries, creating winners and losers. The sample is distributed such that around a third each would lose substantially, stay at around the same level, and gain substantially. Some countries would even end up with negative revenue from compensating tax losses. As shown in Figure 1, countries that stand to gain the most are Guatemala, Mexico, Honduras, Greece, and the United States. On the losing side are Luxembourg, Norway, Kazakhstan, China, and Cyprus. In the following analysis, we will investigate the factors determining these differences in outcomes. 


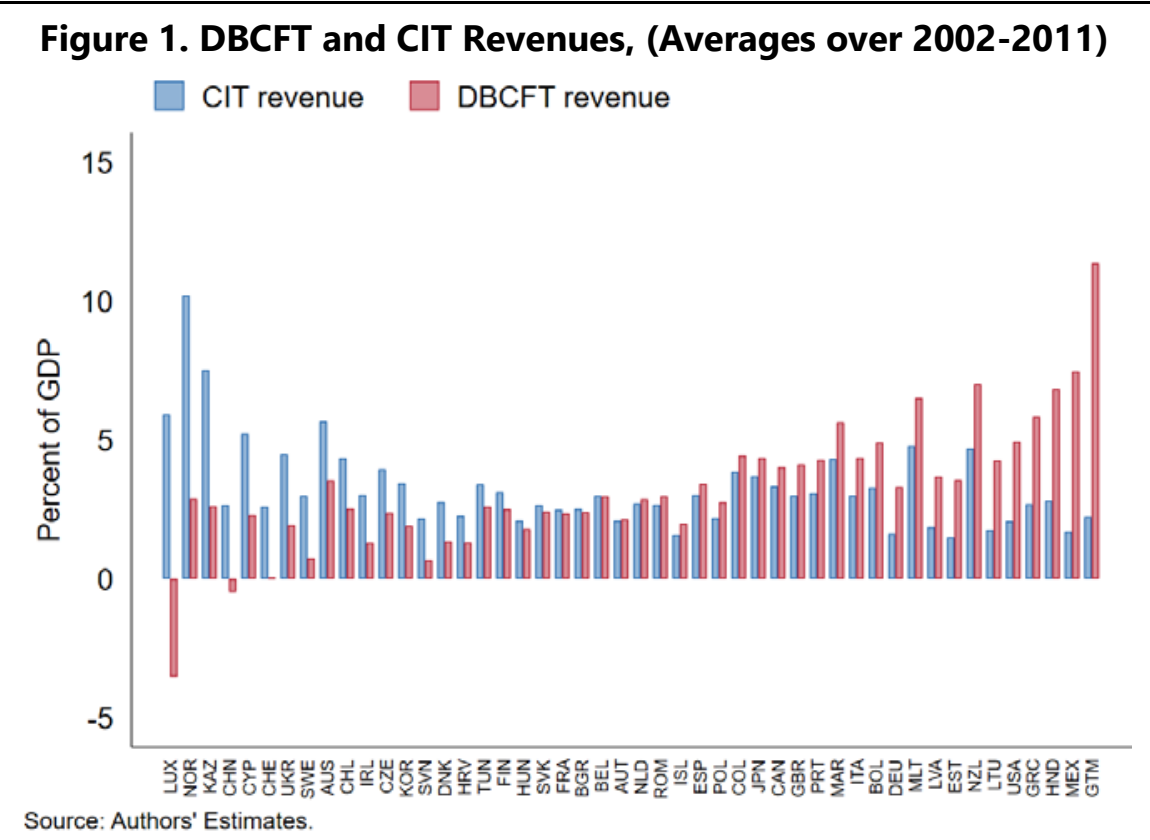

For the United States we can compare our results to a study by Patel and McClelland (2017) who use U.S. tax return data to simulate the DBCFT base. They find that the domestic cash-flow tax base is similar to the existing $\mathrm{CIT}$ base. However, once the border-adjustment is taken into account, the DBCFT base is significantly higher, in line with our result.

Another way to illustrate the issue is by considering the tax rate that would need to be charged under a DBCFT to maintain the same revenue as under the current system. Remembering that under DBCFT, the tax rate is irrelevant for location decisions of firms, countries would arguably be able to raise rates compared to the current ones. Tax rates that would maintain revenues in 2011 are shown in Figure 2. This reveals that for two thirds of all countries, the change in rate would be negative or a small increase. Almost 90 percent of countries would be able to maintain revenues with rates of no more than 40 percent. However, for the remaining countries, revenueneutral rates would be very high, so that this is not a realistic option, although the feasible maximum rate is likely much higher than under the current system. Moreover, as seen in Figure 1, some countries would have negative tax bases, which would not allow maintaining revenues at any rate. 


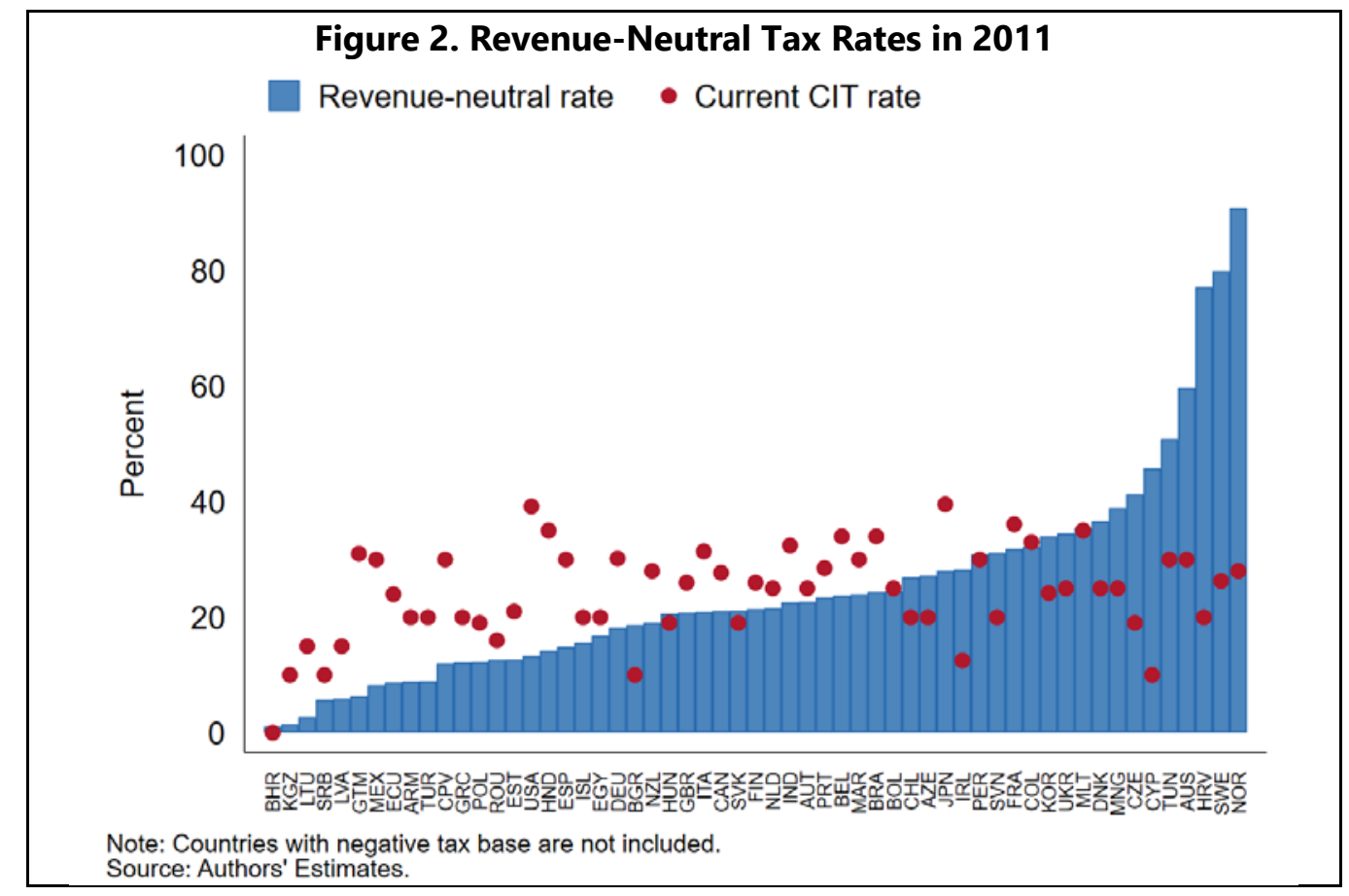

\section{The Role of Trade Balances and Border Adjustment}

Because imports are taxed and exports exempted under the DBCFT, in terms of tax revenue trade deficit countries would be expected to gain from DBCFT adoption, whereas trade surplus countries would lose. As shown in Figure 3, this is indeed true on average, with a clearly negative relationship between the trade balance and the revenue change. Nevertheless, there are still many individual cases where a trade surplus country would gain revenue and vice versa, because one of the other factors outweigh the effect from the trade balance. For example, a country with a trade surplus, but that is currently losing significant revenues from profit shifting, could potentially gain from a DBCFT. 
Figure 3. Trade Balance and Revenue Change, Excluding Resource-Rich Economies (percent of GDP)

- Revenue gain - Revenue loss

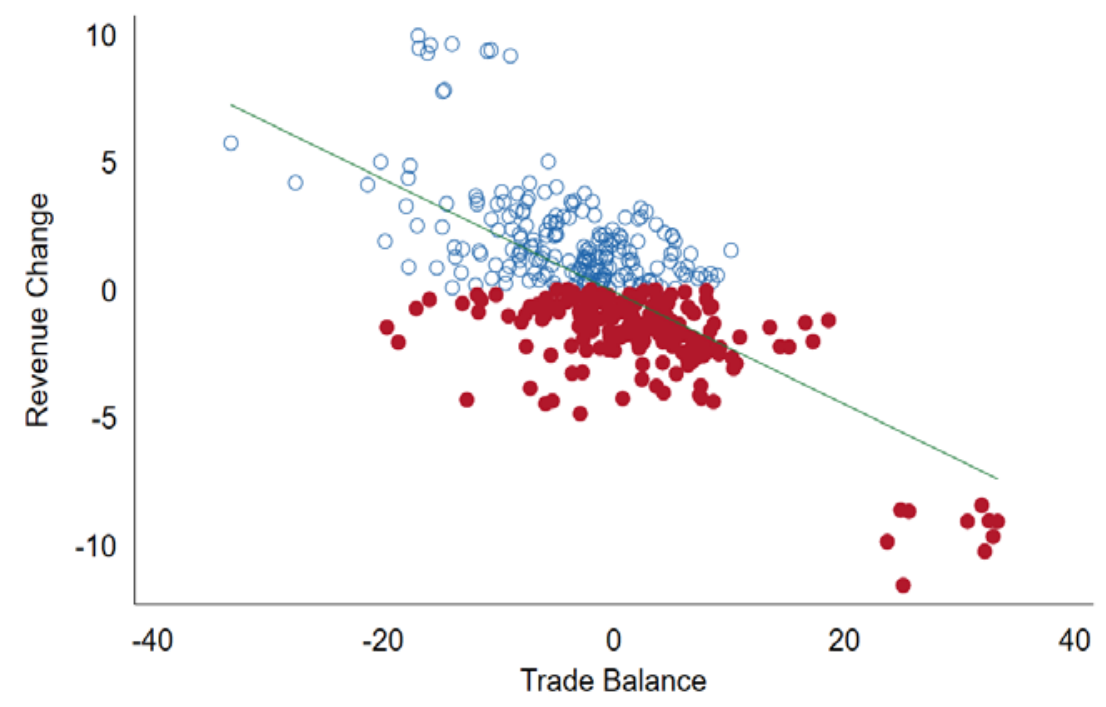

Source: Authors' Estimates.

As shown in Figure 4, the impact of the border adjustment far dominates the impact of moving to a cash-flow base, both in trade surplus and trade deficit countries, although obviously in opposite directions. Even the cash-flow component has opposite effects, reducing the tax base in trade deficit countries and raising it in trade surplus countries. This pattern is in line with higher investment (which is deductible) in trade deficit countries, which can be expected, given that a negative balance of payments implies investments exceeding savings. However, as under a destination base, imported investment goods would not be deductible, it is not surprising that this tax base-reducing effect does not hold after the border adjustment.

Figure 4. Border Adjustment versus Cash Flow Component of Revenue Change

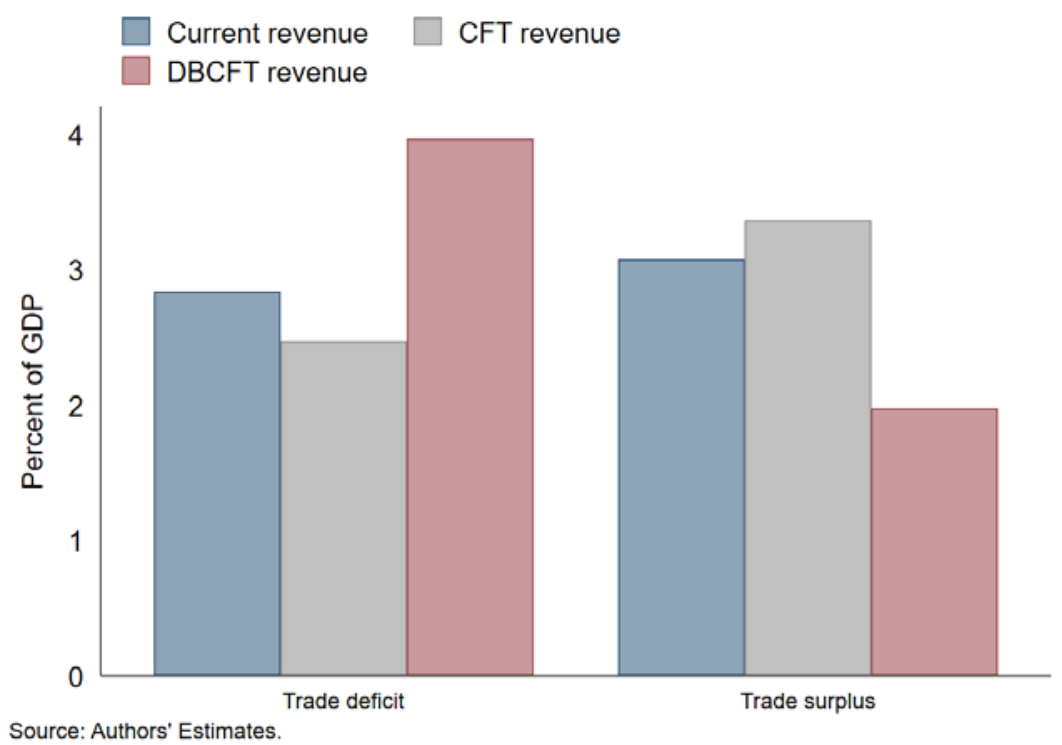




\section{Advanced and Developing Economies}

An important question in evaluating the effect is the distribution of gains and losses between advanced and developing economies. A priori, the relative impact on developing countries is ambiguous. Given their higher growth rates, they can be expected to be capital importers running trade deficits, which would raise revenues-although in practice developing countries are often capital exporters. Moreover, tax incentives are particularly common in developing countries (see for example, Abbas and Klemm (2013)); replacing them with a clean cash-flow tax would be more likely to broaden the base than in advanced economies. On the other hand, developing countries often rely heavily on the resource sector and the taxation of locationspecific rents. While we exclude the countries most reliant on resource revenues (which are analyzed further below), it is still likely that the share of revenues from the resource sector is higher in developing economies.

As shown in the left panel of Figure 5, developing countries would on average be beneficiaries of a move to a DBCFT. Moreover, as shown in the right panel, there is a more general tendency that advanced economies lose more revenue. Among both types of economies there is a wide range covering revenue winners and losers.

As the balanced sample used for these charts does not include that many developing countries, we also repeated the same analysis on a wider unbalanced sample, which yielded the same result. One note of caution regarding developing economies is that the assumption of full compliance might be particularly problematic for them.

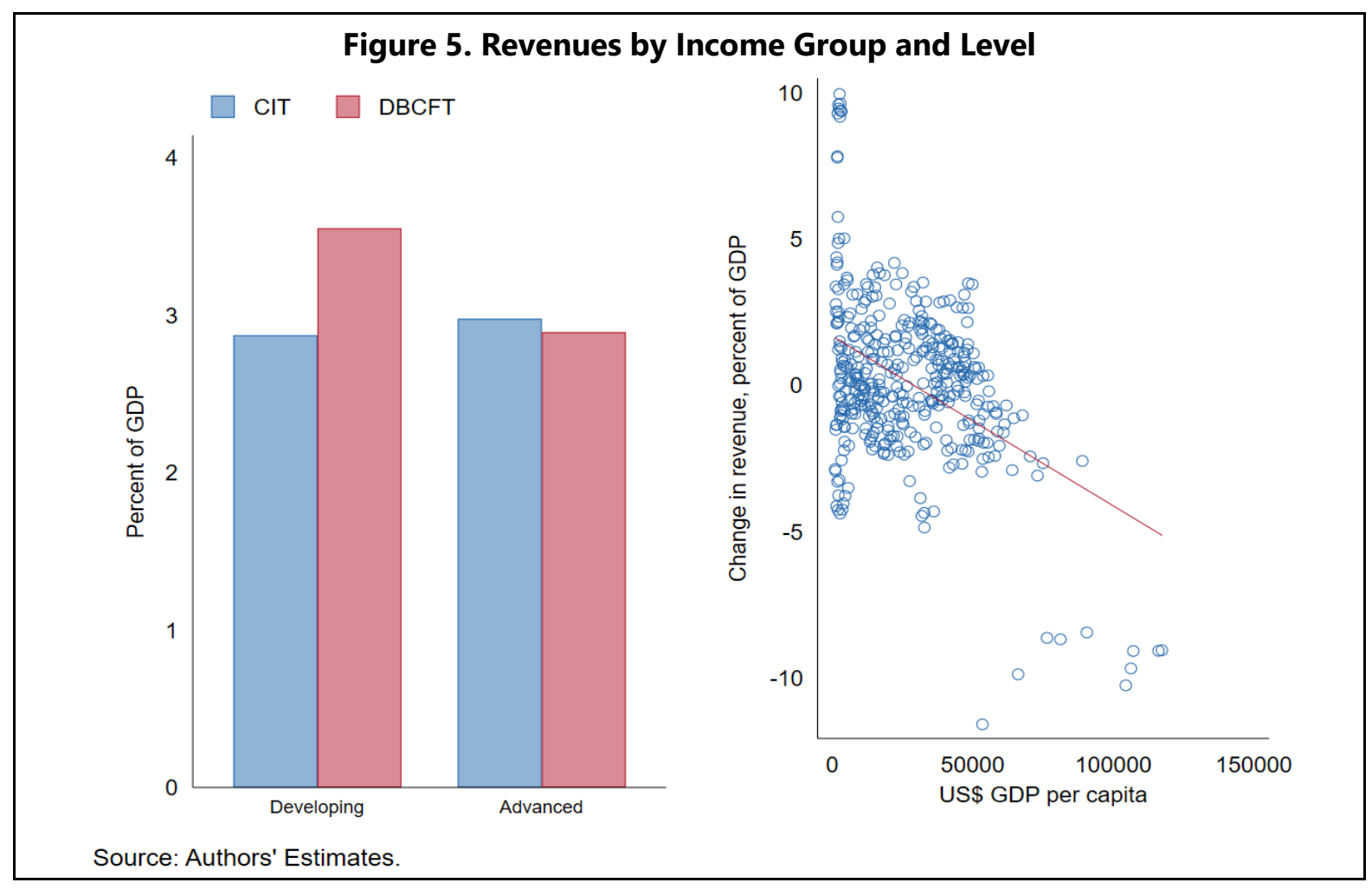




\section{Natural Resources}

Natural resources-and in principle any other location-specific rents-can be taxed efficiently at source and provide an important source of revenue in many countries. Taxing these rents on a destination basis can therefore be expected to dramatically reduce revenues in resource-rich economies. But there are counterarguments.

First, resource rents are typically not taxed only through the CIT, but a host of sector-specific taxes. Such supplementary taxes would not be affected by replacing the standard CIT with DBCFT. The revenue loss would therefore be limited to CIT collected from this sector. Countries wishing to maintain the same level of taxation on the resource sector could raise their sectorspecific taxes. ${ }^{16}$

Second, just because the DBCFT is collected at the destination, it does not follow that its incidence will also occur at the destination. It will depend on whether investors exploiting the resource are residents and when and how they spend their gains (see also Appendix for a more detailed argument):

- If a resident investor exploits a natural resource, then the rent obtained will show up as a stronger trade balance. For the external accounts to balance, this will require imports to rise too (at least ultimately, temporarily the proceeds could be invested abroad-see below for a discussion on trade balance reversals). The imports are, however, taxed, so ultimately revenue will be same as if collected on an origin basis. Another way to think about this is to use the result that the DBCFT is incident on consumption financed out of non-wage income (Auerbach and others, 2017a), including rents from exploiting natural resources.

- If a foreign investor exploits the resource, the rent would equally boost the trade balance. In this case, however, as there is an offsetting outflow on the income balance, the overall balance of payments need not adjust, and no tax is collected in the country where the resource is located (and revenue may be lost if there are deductible costs).

Overall then, resource-rich countries should be expected to lose revenues to the extent that rents in this sector are earned by non-residents. As shown in Figure 6, resource-rich countries would in practice lose revenues on average. It should also be noted, though, that if the graph is done with the entire (unbalanced) sample, which increases the number of resource rich countries, the difference in gains or losses disappears, so this finding is not very robust.

\footnotetext{
${ }^{16}$ See Daniel, Keen, and McPherson (2010) for options on efficient resource-sector taxes.
} 
Figure 6. Revenues by Resource Dependence

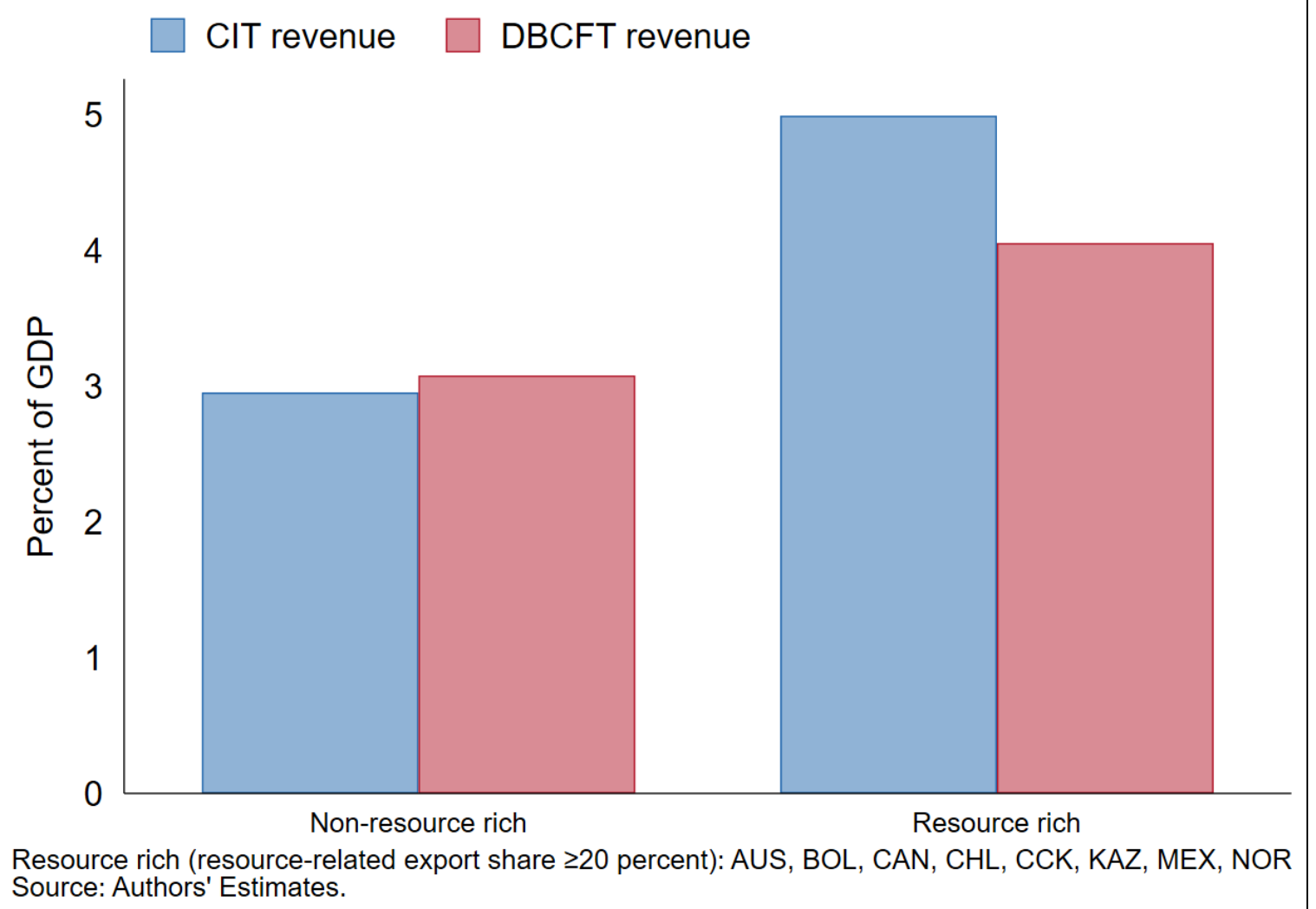

\section{Combined Analysis of Revenue-Determining Factors}

As all the discussed factors behind revenue gains and losses interact, it is useful to undertake a multivariate regression analysis to identify the main correlations. Moreover, using country and year fixed effects estimation on panel data allows us to control for any unobserved countryspecific differences and common shocks.

Table 2 shows that the most important determinants of the revenue gain from moving to a DBCFT are the trade balance, the investment rate, resource rents, and income levels-which all reduce the revenue gain from moving to a DBCFT. This finding holds both in parsimonious regressions (regressions (1) through (3)) and those with more simultaneous control variables (regression (5)). While the income level is important in determining the revenue gain (regressions (3) and (5)), there is no evidence that the relationship between the revenue gain and the most significant explanatory variables is different in advanced economies (regression (4)). 


\begin{tabular}{|c|c|c|c|c|c|}
\hline & (1) & $(3)$ & (2) & (1) & 85 \\
\hline \multirow{2}{*}{ Trade balance } & $-0.227^{\star \star \star}$ & $-0.171^{\star \star \star}$ & $-0.220^{\star \star \star}$ & $-0.260^{\star \star \star}$ & $-0.184^{\star \star \star}$ \\
\hline & $(0.028)$ & $(0.028)$ & $(0.026)$ & $(0.026)$ & $(0.028)$ \\
\hline \multirow[t]{2}{*}{ Investment } & $-0.263^{\star * *}$ & $-0.237^{* * \star}$ & $-0.248^{* \star \star}$ & $-0.311^{\star \star *}$ & $-0.243^{* * *}$ \\
\hline & $(0.043)$ & $(0.048)$ & $(0.043)$ & $(0.042)$ & $(0.044)$ \\
\hline Resource rents & & $\begin{array}{l}-0.087^{* *} \\
(0.038)\end{array}$ & & & $\begin{array}{l}-0.082^{* *} \\
(0.038)\end{array}$ \\
\hline GDP per capita & & & $\begin{array}{l}-0.686^{*} \\
(0.359)\end{array}$ & & $\begin{array}{l}-0.671^{*} \\
(0.379)\end{array}$ \\
\hline Investment ${ }^{\star}$ Advanced & & & & $\begin{array}{l}0.123 \\
(0.082)\end{array}$ & $\begin{array}{l}0.048 \\
(0.099)\end{array}$ \\
\hline Trade balance*Advanced & & & & $\begin{array}{l}0.090 \\
(0.058)\end{array}$ & $\begin{array}{l}0.030 \\
(0.062)\end{array}$ \\
\hline Observations & 1,097 & 889 & 1,097 & 1,097 & 889 \\
\hline R-squared & 0.434 & 0.374 & 0.443 & 0.445 & 0.387 \\
\hline Country FE & YES & YES & YES & YES & YES \\
\hline Year FE & YES & YES & YES & YES & YES \\
\hline Number of countries & 73 & 71 & 73 & 73 & 71 \\
\hline
\end{tabular}

\section{B. Adjusting Results for Profit Shifting}

As noted, one can take Auerbach's (2017b) argument about profit shifting not affecting the measured tax base of a DBCFT, in which case the analysis above is valid. Alternatively, one may argue that mismeasurement of the various components resulting from profit shifting is different, because of the estimation and data collection methods, in which case an adjustment would make a difference.

To see whether our results hold up when using data adapted for profit shifting, we recalculate DBCFT revenues using adjusted data and compare them to the unadjusted results. Figure 7 shows the results and reveals that for most countries the correction is very small. The median difference in revenues under both methods is just 0.04 percent of GDP. ${ }^{17}$ This small figure is not due to small adjustments, but rather to the counteracting impact of the revenue impact from adjusting the trade balance (median adjustment: 0.17 percent of GDP) and the gross operating surplus ( 0.13 percent of GDP).

There are, however, some exceptions to this general finding of a small impact of profit shifting on DBCFT revenues. In three countries, the net adjustment to tax revenues exceeds 1 percent of

${ }^{17}$ This is calculated as $\tau\left(\Pi_{\text {ajusted }}^{T W Z}-\Pi^{T W Z}-(M-X)_{\text {adjusted }}^{T W Z}+(M-X)^{T W Z}\right)$. 
GDP in absolute value. The countries are Luxembourg (+6.6 percent of GDP), Ireland (+3.2 percent of GDP), and Cyprus (+2.4 percent of GDP). In all cases, the adjustment on the trade balance by far dominates the adjustment to the gross operating surplus. ${ }^{18}$ Another two countries have adjustments exceeding $1 / 4$ percent of GDP: the Netherlands ( +0.7 percent of GDP) and Belgium (+0.3 percent of GDP). Luxembourg is particularly noteworthy, because the adjustment turns its tax base positive.

\section{Figure 7. The Impact of Adjusting for Profit Shifting}

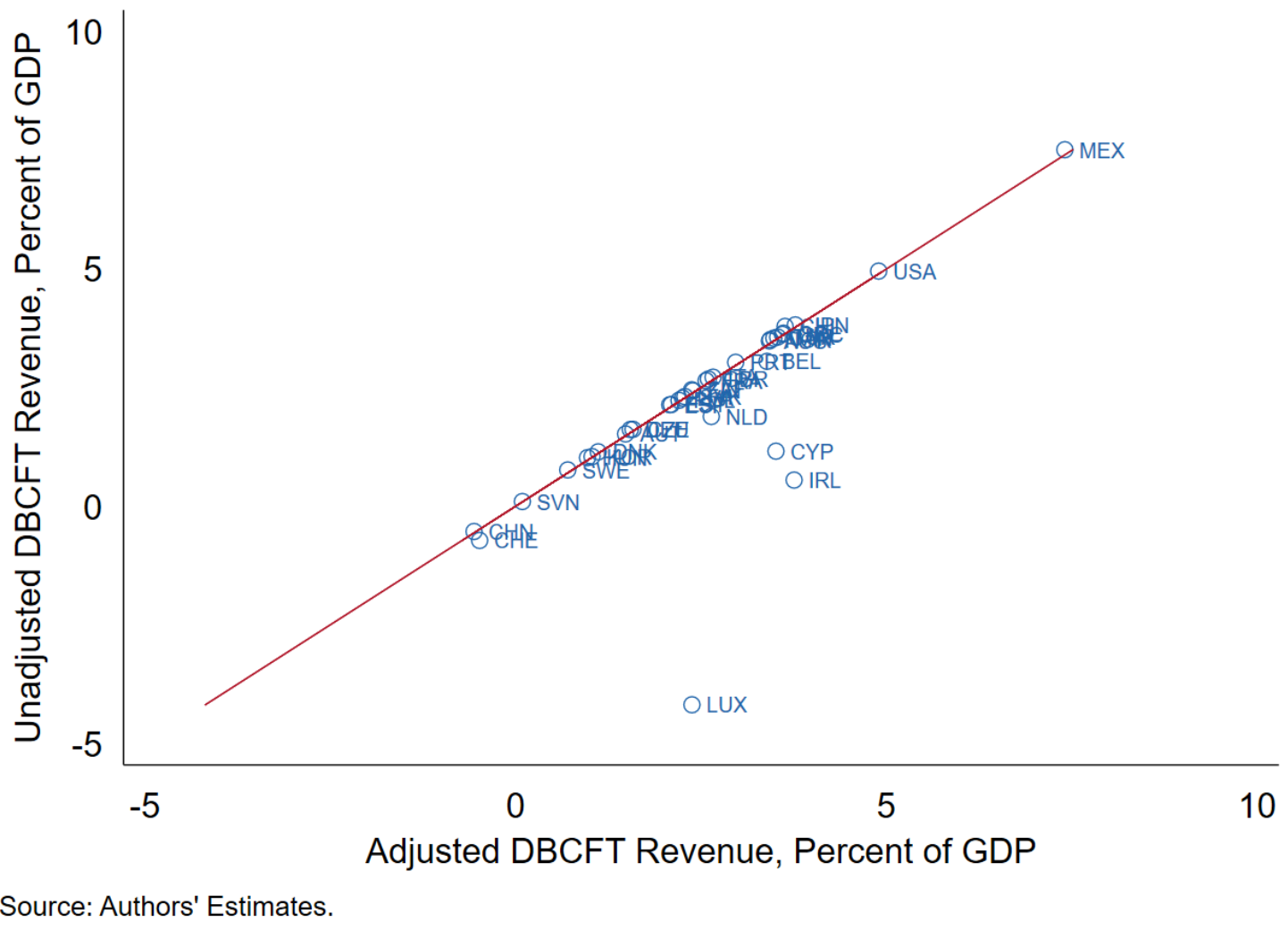

\section{Further Considerations}

\section{Trade Balance Reversals}

Countries cannot continually record current account surpluses or deficits. Balance of payment deficits will add to foreign liabilities until an adjustment takes place. One complication in this

\footnotetext{
${ }^{18}$ Because of this, reducing the adjustment to the gross operating surplus to estimate the share of the nonfinancial sector does not make an important difference to the analysis.
} 
context is that valuation gains or losses are not fully accounted in the balance of payments, so that the international investment position may change differently from the cumulation of the balance of payments. ${ }^{19}$ The trade balance need not always reverse, as a negative trade balance could be financed from a positive income balance. Nevertheless, in a typical case, extended trade deficits can be expected to be followed by future trade surpluses. Hence countries that would gain from a DBCFT on introduction, may lose some of the revenues in the future.

To gauge the size of that risk, Figure 8 plots the net international investment position against the trade balance. The countries that increase their revenues in case of DBCFT adoption are marked blue and tend to be located toward the left side of chart, where trade balances are weaker. Revenue losing countries are marked red and tend to be located toward the right side of the graph. The vertical line, which separates the trade surplus from the deficit countries, provides a good indication of likely short-term revenue loss or gain, but is not a perfect demarcation line as other factors also determine the gain. The horizontal line separates the countries that have a greater chance of losing revenues in the future: they are the countries below this line, as they can be expected to have trade surpluses at some point. The four quadrants thus determine the impact of the border tax adjustment. Countries in the top right quadrant can be expected to lose revenue now, but gain in the future, in the bottom right they lose both now and in the future, in the top left they gain now and lose in the future, and in the bottom left they always gain. Any country close to the intersection of both lines should not expect much of an impact now or later. Because of factors beyond the border adjustment, some countries are outliers to this general pattern. Germany and Belgium, for example, would gain revenues now-even though they lose from the border adjustment part of the DBCFT.

\footnotetext{
${ }^{19}$ Another issue is that countries that issue reserve currency could permanently run deficits, financed by the demand for reserve currency by other countries.
} 


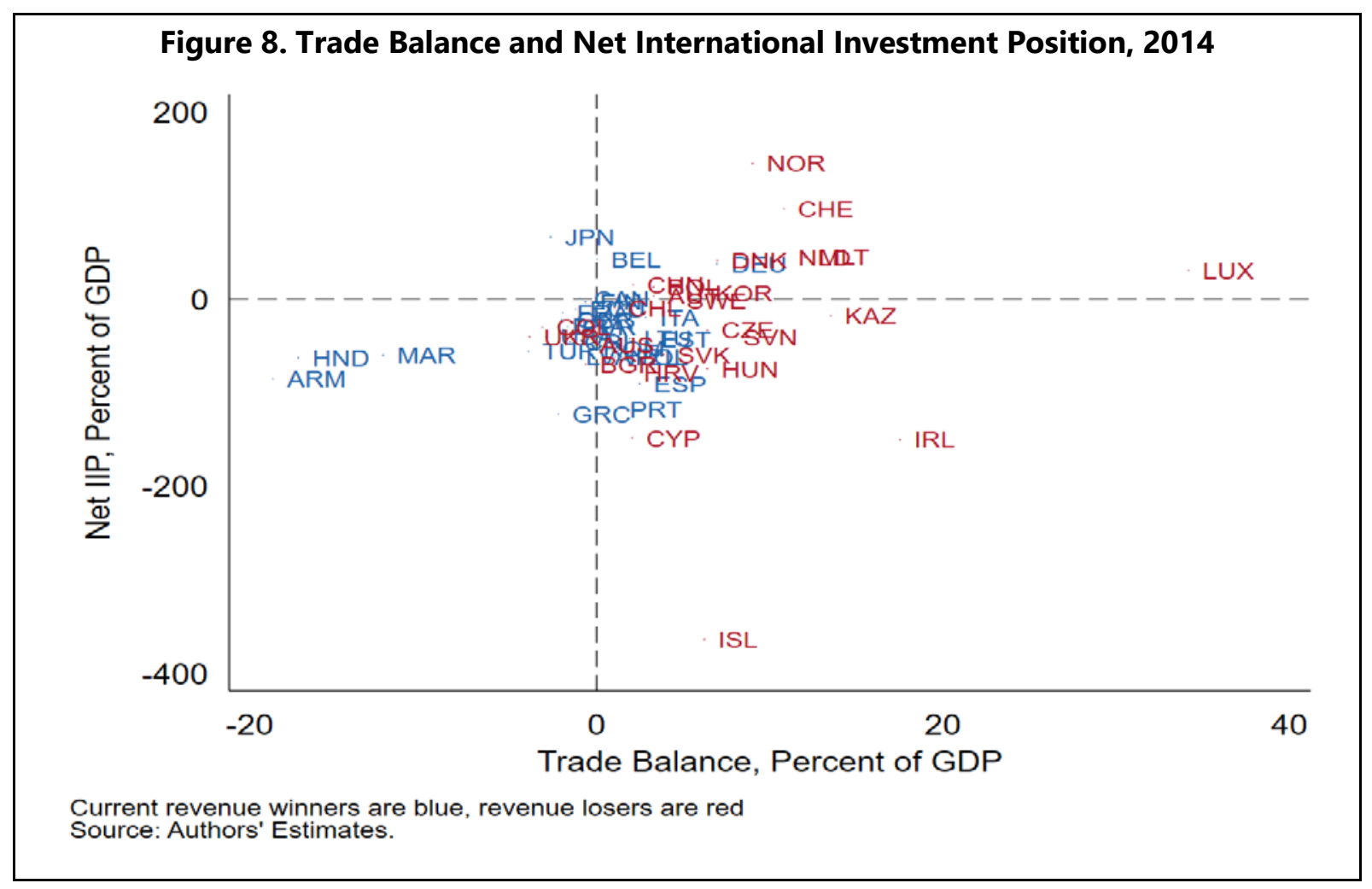

\section{Volatility}

While the analysis so far has focused on the amount of revenue raised, another important consideration is the regularity of revenues. The DBCFT can be expected to be more volatile than a standard CIT, because investment, which is a flow variable, will vary more over the cycle than depreciation, which is linked to a stock and averages out the flows of various past years. Another reason for expecting greater revenue volatility is the immediate refund of tax on losses, while most current CIT systems merely allow the carry forward (or very limited carry back) of losses, smoothing revenues over time. The impact of the border adjustment is less clear: in countries where the economic cycle is strongly dependent on demand from the rest of the world, the nontaxation of exports could reduce volatility, but in countries where domestic demand is more volatile, not taxing export earnings could increase volatility.

To assess this empirically, we calculate the standard deviation of tax revenues under both systems. Figure 9 presents the results and shows that the DBCFT is indeed more volatile on average, but not in every country. These results were calculated for the longer panel to allow calculation of the standard deviation of a longer period. Calculated on the shorter and wider panel, the difference between both average standard deviations is much smaller. 
Figure 9. Standard Deviation of Annual Revenue, 2000-2014

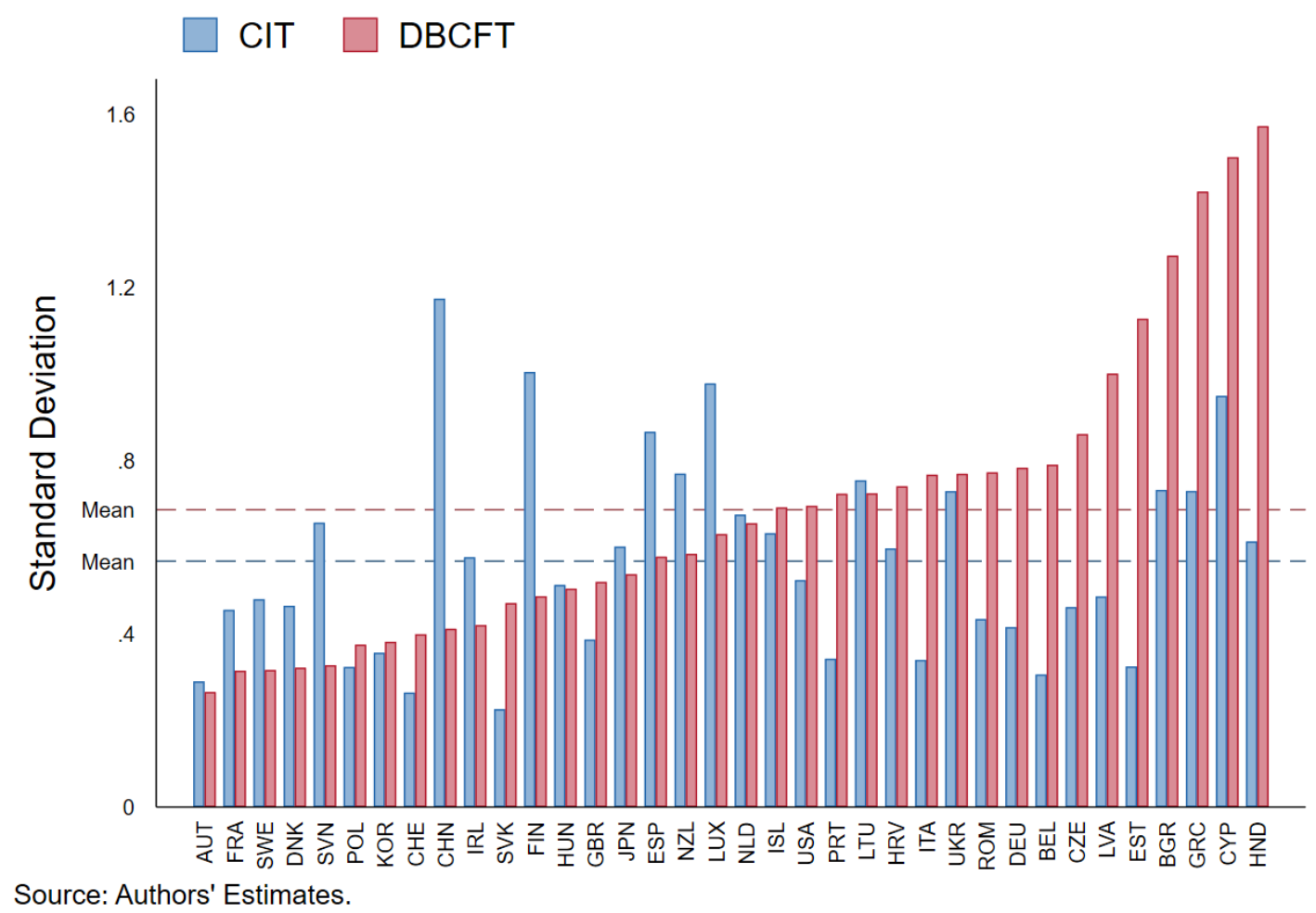

\section{Cyclicality}

Another important consideration in assessing a tax is its revenue performance and its cyclical impact. There is a natural tension between the aim to have taxes with countercyclical impact, i.e., that naturally decline in recessions, and with the need for regular revenue provision discussed above, and countries may place more importance on one or the other, depending on their circumstances, but both need to be considered in evaluating a tax.

The CIT, as a tax on profit, acts as an automatic stabilizer, because profits are highly cyclical. On one hand the DBCFT may weaken this aspect, because investment, which is highly cyclical, is deductible, reducing tax payments during boom times. On the other hand, the immediate refund of tax on losses, would be a powerful counter-cyclical aspect in times of recession. Which of these effects dominates over the cycle is an empirical question. We address it by running a standard regression from the literature assessing cyclicality of fiscal policy: ${ }^{20}$

\footnotetext{
${ }^{20}$ See Appendix in Klemm (2014) for a table summarizing the specifications used in the literature.
} 


$$
R_{i t}=\beta_{0}+\beta_{1} R_{i t-1}+\beta_{2} I+f_{i}+\varepsilon_{i t}
$$

where $\beta$ are regression coefficients, $I$ is an indicator of the cyclical position, such as the output gap or the growth rate, $f$ is a country fixed effect, and $\varepsilon$ an error term. Subscripts $i$ and $t$ indicate country and time.

The regression is estimated on the full sample of countries, as well as on a sample restricted to advanced economies, because the empirical literature on cyclicality has generally found that advanced economies have more countercyclical fiscal policy. ${ }^{21}$ The combination of a lagged dependent variable and a fixed effect can lead to biased results. This bias, however declines with the number of time periods (Nickel, 1981). Given that our panel is quite long with 14 to 19 time periods on average per country, depending on the specification, the bias should be minimal. We also repeated all regressions without a lagged dependent variable, obtaining very similar results. Another important consideration in estimating equation (6) is the endogeneity of the cyclical position, because this can be affected directly by tax policy. To address this, we instrument it by its lagged value.

The results (Table 3) show that the existing CIT is acyclical or countercyclical, depending on whether we use the output gap or growth rate as an indicator. The DBCFT, however, is always more strongly aligned with the cycle: in regressions using the output gap it is procyclical, and in those using the growth rate it is acyclical.

Overall, the conclusion is then the DBCFT is less likely to act counter-cyclically. This is particularly regrettable, as it is also more volatile. In trading off revenue certainty with automatic stabilization, the DBCFT appears not to be a tradeoff, but a deterioration in both dimensions.

\begin{tabular}{|c|c|c|c|c|c|c|c|c|}
\hline \multirow[t]{2}{*}{ Dependent variable } & \multicolumn{4}{|c|}{ CIT revenue } & \multicolumn{4}{|c|}{ DBCFT revenue } \\
\hline & (1) & (2) & (3) & (4) & (5) & (6) & (7) & (8) \\
\hline Sample & \multicolumn{2}{|c|}{ Full } & \multicolumn{2}{|c|}{ Advanced economies } & \multicolumn{2}{|c|}{ Full } & \multicolumn{2}{|c|}{ Advanced economies } \\
\hline $\begin{array}{l}\text { Lagged depenent } \\
\text { variable }\end{array}$ & $\begin{array}{l}0.599^{\star \star *} \\
(0.0626)\end{array}$ & $\begin{array}{l}0.641^{\star \star \star} \\
(0.0306)\end{array}$ & $\begin{array}{l}0.734^{\star * *} \\
(0.0316)\end{array}$ & $\begin{array}{l}0.754^{\star * *} \\
(0.0287)\end{array}$ & $\begin{array}{l}0.772^{\star \star \star} \\
(0.0397)\end{array}$ & $\begin{array}{l}0.770^{* * *} \\
(0.0219)\end{array}$ & $\begin{array}{l}0.844^{\star \star *} \\
(0.0301)\end{array}$ & $\begin{array}{l}0.856^{\star \star *} \\
(0.0319)\end{array}$ \\
\hline Output gap & $\begin{array}{l}-0.0254 \\
(0.0264)\end{array}$ & & $\begin{array}{l}-0.0114 \\
(0.0122)\end{array}$ & & $\begin{array}{l}-0.0289^{* *} \\
(0.0142)\end{array}$ & & $\begin{array}{l}-0.0320^{* *} \\
(0.0153)\end{array}$ & \\
\hline GDP growth & & $\begin{array}{l}0.0819 * \star \star \\
(0.0256)\end{array}$ & & $\begin{array}{l}0.0691^{\star \star \star} \\
(0.0127)\end{array}$ & & $\begin{array}{l}0.00652 \\
(0.0195)\end{array}$ & & $\begin{array}{l}-0.0324 \\
(0.0227)\end{array}$ \\
\hline Observations & 1,473 & 2,179 & 666 & 676 & 952 & 1,143 & 612 & 617 \\
\hline Countries & 89 & 154 & 35 & 35 & 61 & 78 & 32 & 32 \\
\hline
\end{tabular}

\footnotetext{
${ }^{21}$ E.g., Gavin and Perotti (1997), Alesina, Campante, and Tabellini (2008).
} 


\section{Loss-Making Firms}

Under a DBCFT, losses would trigger immediate tax refunds rather being carried forward. This is needed for it to function, as some firms, notably those whose sales are mostly to foreign customers, would be expected to have systematic tax losses. Loss carry-forward, even with an interest rate, would therefore not be an option.

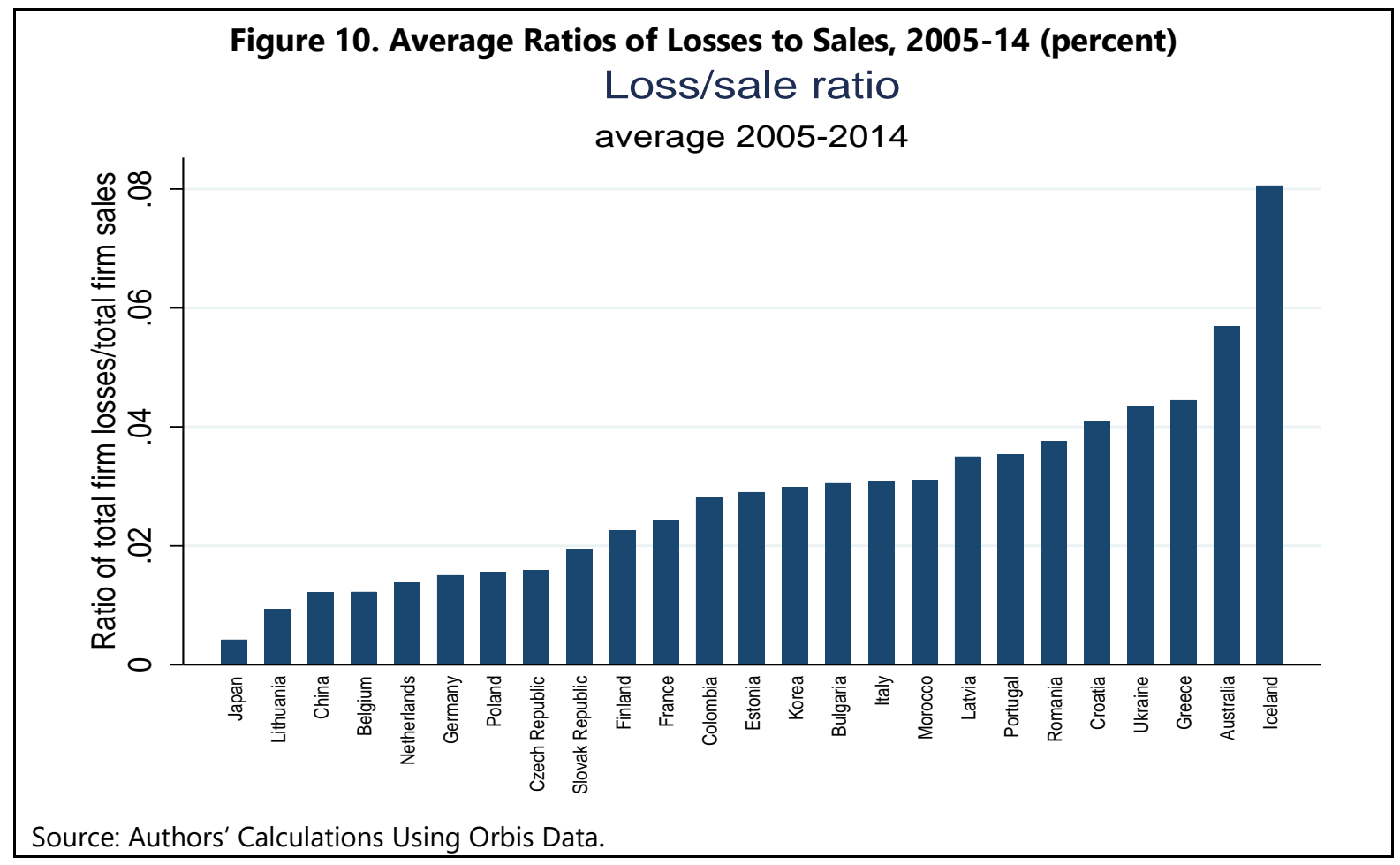

This poses another risk to public finances. The calculated DBCFT revenue estimates already include the impact of losses, as the starting point is the corporate operating surplus, which nets off all profits and losses in the economy. However, it does not include any future losses that may occur, possibly fraudulently, as a result of the availability of refundable tax credits. The extent to which this may happen is unknown, but data on the prevalence of losses may give a rough indication of where such risks may be high (Figure 10).

\section{Unilateral Adoption}

\section{Theory and Methodology}

Thus far, our focus has been on the revenues and implications for the countries that implement a DBCFT. In the unlikely case of all countries moving simultaneously to a DBCFT, that would be the only relevant scenario. More likely is that one or a few countries introduce a DBCFT, which would have repercussions on all other countries. Multilateral adoption would put an end to known forms of tax competition and profit shifting. Unilateral adoption, however, would imply an extreme intensification of incentives to shift profits or real investment that earns export-related rents into the DBCFT country. 
Profit shifting can occur through transfer price manipulation, royalty payments, and the location of debt. The first two would increase measured exports of the DBCFT country and imports of the $\mathrm{CIT}$ country. The latter would be reflected in international interest flows. There are no tax implications of any of these profit-shifting methods for the DBCFT country, as exports and interests are untaxed. The tax base of the CIT country, however, would be reduced.

Relocation of real activity to the DBCFT country could also occur. In case of activities that just break even, there would be no incentive: while exports would be untaxed, production costs are also higher in the DBCFT country, because of the adjustment in real exchange rates. However, investment that leads to rent-earning export activity would face an incentive to relocate. Again, there are no direct tax implications for the DBCFT country, but there may be indirect consequences, for example if employment rises. For the country maintaining origin-based taxes, there is both a direct loss of revenue, as well as any indirect effect from losing employment.

Focusing on the direct tax consequences for countries maintaining origin-based CITs, we calculate the expected loss, based on elasticities from the literature. This literature relates profitshifting or real investment decisions to changes in relative tax rates between countries (or sometimes to the absolute tax rate of the host country). In the case of a DBCFT country, the relevant tax rate is then zero. For each country, assuming that their own tax rate remains constant, the relative change in tax rates is therefore equal to the original tax rate in the DBCFT country (which is cut to zero), weighted by the importance of the DBCFT country. Specifically, we follow the specification used in Beer, Klemm, and Matheson (2018). ${ }^{22}$ This method separates the change in tax revenues into three different channels: real investments, profit shifting, and policy responses. We set the policy response to 0 , to calculate the impact in a no policy change scenario. We will later allow for DBCFT adoption as the policy response. The expected change in tax revenue of a CIT country is then: ${ }^{23}$

$$
\frac{d T_{c}}{T_{c}}=\left(\alpha_{c} \varepsilon_{K}+\varepsilon_{S}\right) \omega_{c, D} t_{D}
$$

where $T$ is the tax revenue of country $c$, $\alpha$ is the capital intensity, $\varepsilon$ are the elasticities for real investment (subscript $K$ ) and profit shifting (subscript $S$ ) with respect to the tax rate, $\omega$ is bilateral weight between the CIT and DBCFT country, and $t_{D}$ is the corporate income tax rate of the DBCFT country.

To parametrize the equation, we use the standard assumption of $1 / 3$ for the capital intensity. For the elasticity of capital we use 2.4 based on the meta study by De Mooij and Ederveen (2008), and for the profit-shifting elasticity we use 1.5 based on the meta study by Beer, De Mooij, and Liu (2018). The weight should reflect how closely linked both economies are in terms of allowing

\footnotetext{
22 This is built on a model inspired by Hines and Rice (1994) and Huizinga and Laeven (2008).

${ }^{23}$ Strictly, this gives the change in revenues of multinationals. To gauge the impact on total tax revenues, this should be multiplied by the share of profits earned by multinationals (including domestically-owned ones) in total profits. We do not have these data for most countries, so we slightly overestimate revenue losses.
} 
capital to move between both. As this is a theoretical concept, based on potential rather than actual movements, there is no perfect measure for it. As an approximation we use existing FDI links in both directions:

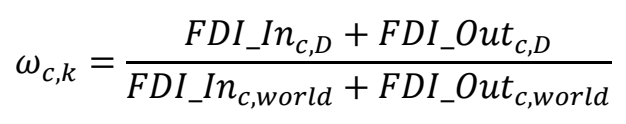

where FDI_In is the FDI stock in country $c$ and FDI_Out is the stock owned abroad by country $c$. The second subscript indicates the partner, either the DBCFT country $D$ or the whole world.

To calculate the impact, we need to pick a first mover to introduce a DBCFT. To give a flavor of possible differences we use (i) the United States, as the largest and a highly-integrated economy, (ii) the United Kingdom, as a smaller advanced economy that is also very highly integrated, and

(iii) India, and (iv) Brazil, as two emerging markets. The choice is purely illustrative and does not imply any judgement about the likelihood of such a reform in those countries.

\section{Results}

Figure 11 shows the results of the simulation using data for 2011. If the United States adopted a DBCFT, resulting revenue losses would be quite high, especially in countries like Mexico and Canada that have very close economic links. The spillovers would be lower if the United Kingdom adopted such a tax, but still sizeable in some economies. If Brazil or India adopted a DBCFT, the impact on the rest of the world would be much smaller, although all of these findings are subject to the caveat that current FDI links are only a rough proxy for economic links between countries. 
Figure 11. Revenue Spillovers from Unilateral DBCFT Adoption, 2011
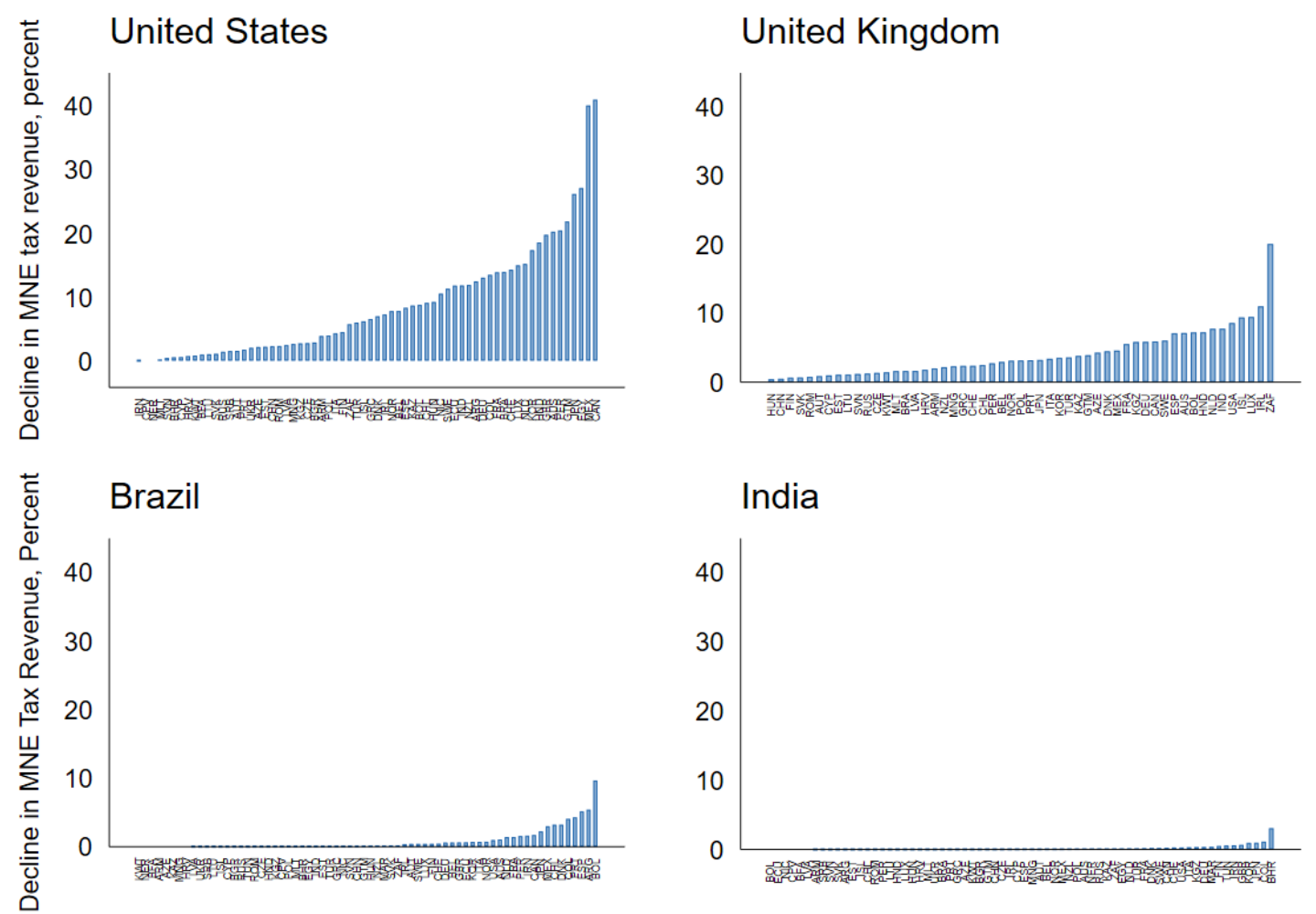

Source: Authors' Estimates.

\section{Incentives for Policy Reactions}

There is an empirical literature on fiscal reaction functions, estimating how countries react to tax cuts elsewhere, recently surveyed by Leibrecht and Hochgatterer (2012). One possible approach for non-DBCFT countries would be to think of the DBCFT country as a CIT cut to zero, and then react accordingly by reducing their own tax rate to regain competitiveness. Another option-and the one focused on here-is to follow by adopting a DBCFT as well. This would reduce revenues in some countries, as calculated above, but is likely to be much less costly than a massive reduction in the tax rate. In some cases, the revenue loss from DBCFT adoption may even be smaller than the revenue loss from staying put and suffering from profit and capital outflows.

Figure 12 compares the revenue impact of different policy choices following the hypothetical adoption of a DBCFT in the United States in 2011, with the dotted line indicating equal revenue impacts. If a country also adopts a DBCFT, there is no revenue loss from profit shifting and the revenue gain or loss, as calculated in Section IIIA, applies and is marked on the horizontal axis. As before, the losses under a DBCFT are averaged over the time span of the main sample to address the high volatility of the DBCFT. Without a DBCFT, there are revenue losses from profit shifting to DBCFT country (i.e., the United States in this example), depicted on the vertical axis. Countries that gain revenue by adopting a DBCFT are marked green. Countries that lose revenue by adopting a DBCFT but would lose even more revenue if staying with a CIT are marked orange. 
Finally, countries that would lose more from adopting a DBCFT than from staying put are marked red.

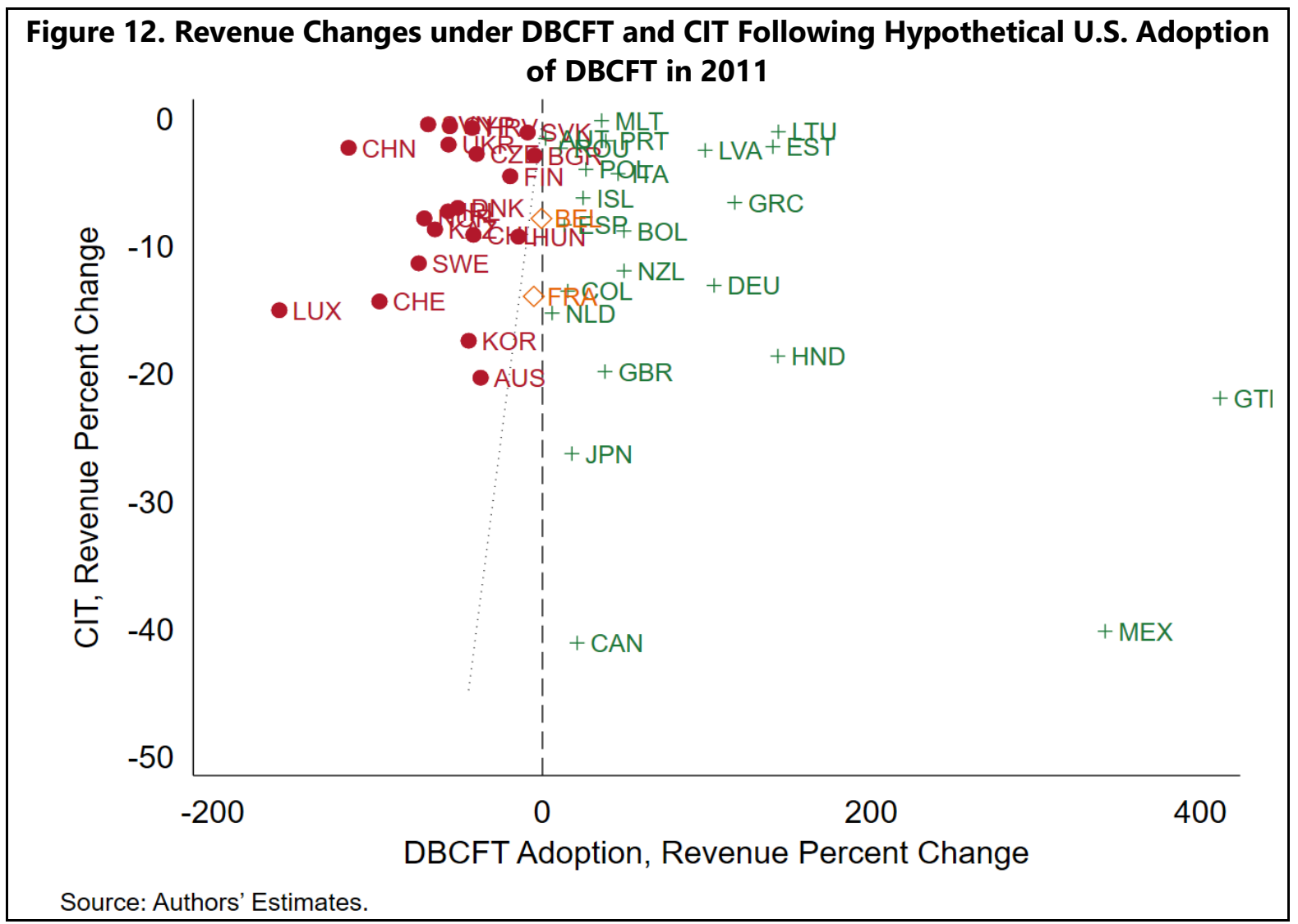

If, following adoption in the United States (or any other country), there is no backlash in terms of a legal challenge or retaliation, then the green (i.e., revenue-gaining) countries have a clear incentive also to introduce a DBCFT. Equally the orange countries have an incentive to follow to minimize their losses. Once all of these countries adopt a DBCFT, the losses of the red countries will rise further, as now many more of their economically-linked partners have a DBCFT.

Figure 13 shows the revenue losses for countries under the scenario under which all green and orange countries of Figure 12 adopt a DBCFT. We see that a further three countries now have an incentive to adopt a DBCFT as this would entail lower revenue losses than maintaining a sourcebased CIT. In principle further rounds are possible, but as these three additional countries are small, no further reaction occurs in this particular sample. Ultimately, further countries might introduce a DBCFT even if it is not the revenue-maximizing option, because they might value the higher investment. Some countries, however, would face massive revenue losses under the DBCFT—with even negative revenues in some cases as noted-imposing a high cost on the option of following with DBCFT adoption. 
Figure 13. Second-Round Spillovers

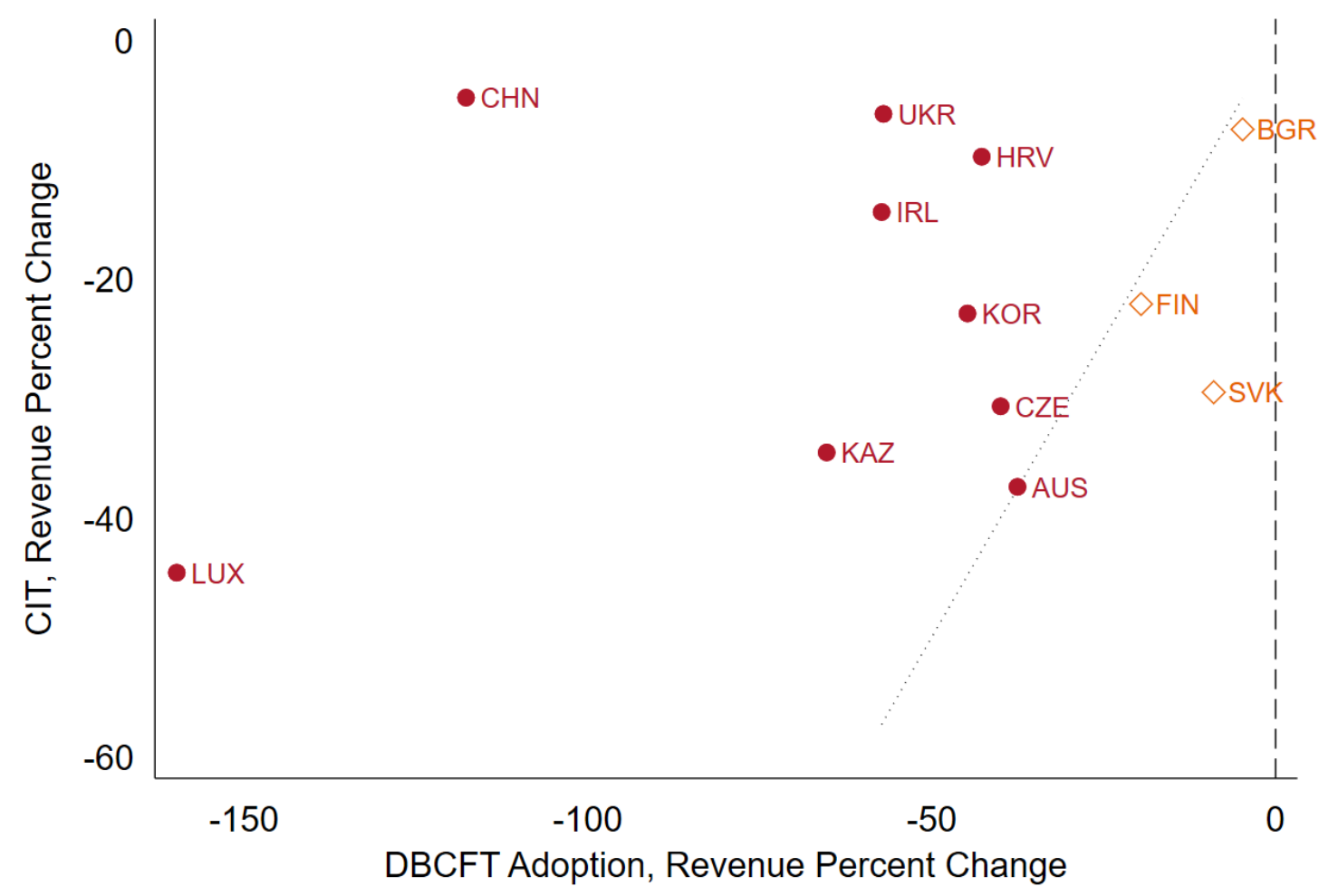

Source: Authors' Estimates.

\section{Conclusion}

This paper has provided estimates of DBCFT revenues using national accounts data. On average, a universally adopted DBCFT surprisingly generates a similar level of revenue as the CIT, but some countries lose while others win. Countries with a large trade surplus would face the largest decline in revenue, at least in the short term. We find no evidence that developing countries lose more revenue than developed countries - if anything, results suggest that the opposite pattern is more likely. Natural resource-rich countries, on average, would generate lower DBCFT revenue than CIT revenue, but would still have additional taxes at their disposal. Other factors such as loss-making firms and revenue volatility could pose revenue risks for some countries.

Unilateral DBCFT adoption can generate negative spillover effects, which are found to be sizeable if the DBCFT country is large and integrated. We find that spillovers could prompt other countries to adopt a DBCFT, too, either as an immediate reaction, or in some cases in a later round, as a rising number of DBCFT countries raises the cost of maintaining source-based CITs. Some countries, however, would never have a revenue incentive for adopting a DBCFT. 


\section{REFERENCES}

Abbas, A. and A. Klemm, 2013, "A Partial Race to the Bottom: Corporate Tax Developments in Emerging and Developing Economies," International Tax and Public Finance, Vol. 20(4), pp. 596-617.

Alesina, Alberto, Filipe Campante and Guido Tabellini, 2008, "Why is Fiscal Policy Often Procyclical?" Journal of the European Economic Association, Vol. 6(5), pp. 1006-1036.

Auerbach, A., 2017a, "Border Adjustment and the Dollar," AEI Economic Perspectives, February 2017.

2017b, "Demystifying the Destination-Based Cash-Flow Tax," Brookings Papers on Economic Activity, Fall 2017, pp. 409-432.

M.P. Devereux, M. Keen, and J. Vella, 2017a, "Destination-Based Cash Flow Taxation," Oxford University Centre for Business Taxation Working Papers, No. 17/01.

M. P. Devereux, M. Keen, and J. Vella, 2017b, "International Tax Planning Under the Destination-Based Cash Flow Tax," National Tax Journal, Vol. 70, pp. 783-801.

Avi-Yonah, R.S. and K. Clausing, 2017, "Problems with Destination-Based Corporate Taxes and the Ryan Blueprint," Columbia Journal of Tax Law, Vol. 8(2), pp. 229-55.

Barbiero, O., E. Farhi, G. Gopinath, and O. Itskhoki, 2018, "The Macroeconomics of Border Taxes," NBER Working Papers, No. 24702.

Beer, S., R. De Mooij, and L. Liu, 2018, "International Corporate Tax Avoidance: A Review of the Channels, Effect Sizes, and Blind Spots" IMF Working Papers, No. 18/168.

A. Klemm, and T. Matheson, 2018, "Tax Spillovers from U.S. Corporate Income Tax Reform," IMF Working Papers, No. 18/166, 2018.

Bond, S. and M.P. Devereux, 2002, "Cash Flow Taxes in an Open Economy," CEPR Discussion Papers, No. 3401.

Carton, B., E. Fernandez-Corugedo, and B. Hunt, forthcoming, "Corporate Tax Reform: From Income to Cash Flow Taxes," IMF Working Papers.

Daniel, P., M. Keen, and C. McPherson, 2010, "The Taxation of Petroleum and Minerals: Principles, Problems and Practice," Routledge.

De Mooij, R.A. and S. Ederveen, 2008, "Corporate Tax Elasticities: A Reader's Guide to Empirical Findings," Oxford Review of Economic Policy, Vol. 24, pp. 680-697.

Gavin, M. and R. Perotti, 1997, "Fiscal Policy in Latin America," NBER Macroeconomics Annual, Vol. 12 , pp. 11-72. 
Hebous, S. and A. Klemm, 2018, A Destination-Based Allowance for Corporate Equity, IMF Working Papers, No. 18/239.

Hines, J. and E. Rice, 1994, "Fiscal Paradise: Foreign Tax havens and American Business," Quarterly Journal of Economics, Vol. 109(1), pp. 149-182.

Huizinga, H. and L. Laeven, 2008, "International Profit Shifting within Multinationals: A MultiCountry Perspective," Journal of Public Economics, Vol. 92, pp. 1164-1182.

Klemm, A., 2014, "Fiscal Policy in Latin America over the Cycle," IMF Working Papers, No. 14/59.

Leibrecht, M. and C. Hochgatterer, 2012, "Tax Competition as a Cause of Falling Corporate Income Tax Rates: A Survey of Empirical Literature," Journal of Economic Surveys, Vol. 26(4), pp. 616-648.

Nickell, S., 1981, "Biases in Dynamic Models with Fixed Effects," Econometrica, Vol. 49(6), pp. 1417-1426.

Patel, E., and J. McClelland, 2017, "What Would a Cash Flow Tax Look Like for U.S. Companies? Lessons from a Historical Panel," Office of Tax Analysis Working Papers, No. 116, United States Department of Treasury.

Tørsløv, T., L. Wier, and G. Zucman, 2018, "The Missing Profits of Nations," NBER Working Papers, No. 24701.

Ueda, J., 2018, "Estimating the Corporate Income Tax Gap," IMF Technical Notes and Manuals, No. $18 / 02$. 


\section{APPENDIX: INTERNATIONAL REVENUE AND INCIDENCE IMPLICATIONS OF A DBCFT}

This appendix provides a theoretical comparison of the incidence and revenue implications of DBCFT considering different company profiles. The results on incidence have been previously described (e.g., Auerbach and others, 2017a).

The following assumptions are made throughout: A country, labelled DB, introduces a DBCFT are rate $\tau$. There is one other country, labelled ROW, that does not change its tax system. The

currency of country DB appreciates in textbook fashion by exactly $\frac{\tau}{1-\tau}$. Hence there is no adjustment in prices. ${ }^{24}$ Wages are unchanged: as prices are the same, labor supply is unaffected. As wages remain untaxed, labor demand is unaffected. As normal profits are untaxed, investors will not need to shift the DBCFT burden onto labor.

\section{A. First Experiment: Impact of Location of Sales and Production}

As shown in Table A1, the tax collection depends on whether firms are purely domestic operations, exporters, or importers. For now, all firms are assumed to be owned by residents. Domestic firms pay tax on sales less cost. Exporters pay no tax and get a refund on their costs. Importers pay tax on sales but are not allowed a deduction. As long as exports and imports balance, revenue from the external sector will mirror those from domestic operations.

The incidence aligns with the tax payment only in case of a purely domestic operation. For exporters, the appreciation means that their revenues from foreign sales decline. Because they get a tax refund on their costs, their normal profits remain tax free and the rent is reduced by the same amount as if they had sold domestically. Exporters therefore bear the same tax burden, even though they are net recipients of tax refunds. The mirror image applies to importers: while their sales are fully taxable, their costs decline thanks to the appreciation. Despite remitting very high taxes, they bear the same tax on rents as firms producing domestically.

\footnotetext{
24 If the exchange rate were fixed and adjustment occurred through the price level, the same results would be obtained, but given the likely slow adjustment, there may be some time periods of disequilibrium. Going beyond the examples discussed here, which are all about firms, there would be further real differences, because the impact on other nominal assets.
} 
Table A1. Tax Payments and Incidence for Firms Located in DB

\begin{tabular}{lccc}
\hline & $\begin{array}{c}\text { Domestic } \\
\text { operation }\end{array}$ & Exporter & Importer \\
\hline Production & DB & DB & ROW \\
Sales & DB & ROW & DB \\
Sales & $p^{D B}$ & $p^{R O W}=p^{D B}(1-t)$ & $p^{D B}$ \\
Costs & $c^{D B}$ & $c^{D B}$ & $c^{R O W}=c^{D B}(1-t)$ \\
Tax & $\left(p^{D B}-c^{D B}\right) t$ & $-c^{D B} t$ & $p^{D B} t$ \\
payment & & & \\
Net profit & $\left(p^{D B}-c^{D B}\right)(1-t)$ & $\left(p^{D B}-c^{D B}\right)(1-t)$ & $\left(p^{D B}-c^{D B}\right)(1-t)$ \\
Tax borne & $\left(p^{D B}-c^{D B}\right) t$ & $\left(p^{D B}-c^{D B}\right) t$ & $\left(p^{D B}-c^{D B}\right) t$ \\
\hline aCalculated as sales less costs less tax payment. & \\
Source: Authors' calculations. & &
\end{tabular}

To sum up: The tax is equally borne by all types of firms located in DB, irrespective of where they produce and sell their goods. No revenues are collected from exporters, but very high revenues from importers, evening out, provided trade is balanced.

\section{B. Second Experiment: Impact of Ownership}

Firms located in DB could be owned by resident or foreign investors. Moreover, residents of DB could own domestic and foreign firms.

The tax implications are shown in Table A2. The first column shows a domestically-owned firm in $D B$, i.e., it condenses the information of Table A1 into one column. The second column shows the tax consequences for DB residents of owning firms in ROW. Even though no DBCFT is payable when owning a firm abroad (as this analysis abstracts from any foreign tax), the owners still bear the incidence of the DBCFT, because the profits earned in foreign currency are worth less. The third column shows foreign investors owning firms in DB. The investors remit DBCFT just like domestically-owned firms (i.e., depending on where sales take place). However, the foreign investors do not bear any tax burden, because the appreciation compensates them for the tax. Finally, for completeness, firms in ROW owned by ROW investors are not affected by the DBCFT. 
Table A2. Tax Payments and Incidence Depending on Ownership

\begin{tabular}{|c|c|c|c|c|}
\hline $\begin{array}{l}\text { Residence } \\
\text { of owner }\end{array}$ & DB & DB & ROW & ROW \\
\hline $\begin{array}{l}\text { Location } \\
\text { of firm }\end{array}$ & DB & ROW & DB & ROW \\
\hline Net profit & $\left(p^{D B}-c^{D B}\right)(1-t)$ & $\begin{array}{l}p^{R O W}-c^{R O W} \\
=\left(p^{D B}-c^{D B}\right)(1 \\
-t)\end{array}$ & $\begin{array}{l}\left(p^{D B}-c^{D B}\right)(1-t) \\
=p^{R O W}-c^{R O W}\end{array}$ & $p^{R O W}-c^{R O W}$ \\
\hline Tax borne & $\left(p^{D B}-c^{D B}\right) t$ & $\left(p^{D B}-c^{D B}\right) t$ & 0 & 0 \\
\hline $\begin{array}{l}\text { Tax paymen } \\
\text { Domestic } \\
\text { operation }\end{array}$ & $\left(p^{D B}-c^{D B}\right) t$ & 0 & $\left(p^{D B}-c^{D B}\right) t$ & 0 \\
\hline Exporter & $-c^{D B} t$ & 0 & $-c^{D B} t$ & 0 \\
\hline Importer & $p^{D B} t$ & 0 & $p^{D B} t$ & 0 \\
\hline
\end{tabular}

Source: Authors' calculations.

To sum up: tax payments/refunds are only due to firms located in DB, with the tax payment/refund depending on the location of sales, and ownership not having a bearing. The tax incidence, however, depends only on the residence of the firms' owners, and is borne by DB residents.

\section{Untaxed Assets}

DB-residents owning assets denominated in ROW currency, such as bonds or land, also bear the burden of the DBCFT, because of appreciation of DB's currency. No tax is remitted though. There is no difference between owning a foreign firm or fixed asset.

DB-residents owning assets denominated in DB currency (including pensions or benefit rights) do not bear any tax burden.

ROW-residents do not bear any burden on assets denominated in ROW currency and enjoy a gain if they own assets denominated in DB currency, but not subject to DBCFT.

\section{Putting it all Together}

From a government perspective, taxes are collected from all firms located in DB, with tax losses by exporters compensated by revenue on importers, provided they are in equilibrium.

From a taxpayer perspective, however, the burden is borne by rent-earning investors resident in DB with foreign residents unaffected.

This has the following implication: suppose DB's resident own relatively much foreign capital. On introduction this means that they bear a high burden. In the long term this translates into high 
revenues: owning foreign capital entitles them to income streams from abroad, which can finance a trade deficit, which boosts revenues. Hence countries with a strong IIP will ultimately benefit in revenue terms from a DBCFT. ${ }^{25}$ Even though this is collected on imports, the burden is still on residents.

Suppose there is a large location-specific rent earned by exporters in DB (e.g., a natural resource, or network benefit from Silicon Valley). If the asset is domestically owned, the burden of the DBCFT will be borne by owners even though no tax is collected from the exporting firm. The owners will (ultimately) use their income from exports to finance imports, which are taxed. If the asset is foreign owned, however, there is no tax burden. There are revenue losses: the profits of nonresidents weaken the income balance, requiring trade surpluses.

\footnotetext{
${ }^{25}$ Auerbach (2017b) also points out that it will depend on the rates of return on assets. E.g., a negative IIP need not require future trade surpluses, if income earned on the smaller foreign assets is higher than the financing cost of the larger foreign liabilities.
} 